\title{
Baseline characteristics, management, and outcomes of 55,270 children and adolescents diagnosed with COVID-19 and 1,952,693 with influenza in France, Germany, Spain, South Korea and the United States: an international network cohort study
}

\section{AUTHORS}

Talita Duarte-Salles1*, David Vizcaya2, Andrea Pistillo1, Paula Casajust3, Anthony G. Sena4,5, Lana Yin Hui Lai6, Albert Prats-Uribe7, Waheed-UI-Rahman Ahmed7,8, Thamir M Alshammari9, Heba Alghoul10, Osaid Alser11, Edward Burn1,7, Seng Chan You12, Carlos Areia13, Clair Blacketer4,5, Scott DuVall14,15, Thomas Falconer16, Sergio Fernandez-Bertolin1, Stephen Fortin4, Asieh Golozar17,18, Mengchun Gong19, Eng Hooi Tan7, Vojtech Huser20, Pablo Iveli21, Daniel R. Morales22, Fredrik Nyberg23, Jose D. Posada24, Martina Recalde1, 25, Elena Roel1, Lisa M. Schilling26, Nigam H. Shah24, Karishma Shah7, Marc A. Suchard27, Lin Zhang28,29, Ying Zhang19, Andrew E. Williams30, Christian G. Reich31, George Hripcsak16, Peter Rijnbeek5, Patrick Ryan4,16, Kristin Kostka31, Daniel Prieto-Alhambra7

\section{AFFILIATIONS}

1. Fundació Institut Universitari per a la recerca a l'Atenció Primària de Salut Jordi Gol i Gurina (IDIAPJGol), Barcelona, Spain

2. Bayer Pharmaceuticals, Sant Joan Despi, Spain

3. Real-World Evidence, Trial Form Support, Barcelona, Spain

4. Janssen Research \& Development, Titusville, NJ, USA

5. Department of Medical Informatics, Erasmus University Medical Center, Rotterdam, The Netherlands

6. School of Medical Sciences, University of Manchester, UK

7. Centre for Statistics in Medicine (CSM), Nuffield Department of Orthopaedics, Rheumatology and Musculoskeletal Sciences (NDROMS), University of Oxford, UK

8. College of Medicine and Health, University of Exeter, St Luke's Campus, Heavitree Road, Exeter, EX1 2LU, UK.

9. Medication Safety Research Chair, King Saud University, Saudi Arabia

10. Faculty of Medicine, Islamic University of Gaza, Palestine

11. Massachusetts General Hospital, Harvard Medical School, USA

12. Department of Biomedical Informatics, Ajou University School of Medicine, Suwon, South Korea

13. Nuffield Department of Clinical Neurosciences, University of Oxford, Oxford, OX3 9DU, UK

14. Department of Veterans Affairs, Salt Lake City, UT, US

15. University of Utah School of Medicine, Salt Lake City, UT, US

16. Department of Biomedical Informatics, Columbia University, New York, NY, US

17. Regeneron Pharmaceutical, NY USA

18. Department of Epidemiology, Johns Hopkins Bloomberg School of Public Health, MD USA

19. DHC Technologies Co. Ltd. Beijing, China

20. Lister Hill National Center for Biomedical Communications, National Library of Medicine, National Institutes of Health, Bethesda, MD, USA

21. Bayer AG, Wuppertal, Germany

22. Division of Population Health and Genomics, University of Dundee, UK

23. School of Public Health and Community Medicine, Institute of Medicine, Sahlgrenska Academy, University of Gothenburg, Gothenburg, Sweden 
medRxiv preprint doi: https://doi.org/10.1101/2020.10.29.20222083; this version posted October 30, 2020. The copyright holder for this preprint

(which was not certified by peer review) is the author/funder, who has granted medRxiv a license to display the preprint in perpetuity.

It is made available under a CC-BY 4.0 International license.

24. Department of Medicine, Stanford University, USA

25. Universitat Autònoma de Barcelona, Spain

26. Data Science to Patient Value Program, Department of Medicine, University of Colorado Anschutz Medical Campus, US

27. Department of Biostatistics, Fielding School of Public Health, University of California, Los Angeles, USA

28. School of Population Medicine and Public Health, Peking Union Medical College and Chinese Academy of Medical Sciences, China

29. Melbourne School of Population and Global Health, The University of Melbourne, Australia

30. Tufts Institute for Clinical Research and Health Policy Studies, US

31. Real World Solutions, IQVIA, Cambridge, MA, USA

\section{Corresponding author}

Talita Duarte-Salles

Fundació Institut Universitari per a la recerca a l'Atenció Primària de Salut Jordi Gol i Gurina

(IDIAPJGol)

Gran Via Corts Catalanes, 587 àtic

08007 Barcelona - Spain

Tel: +34935824342

Email: tduarte@idiapigol.org

Key words: COVID-19; pediatrics; hospital admission; symptoms; fatality 
What is already known on this topic?

- Most of the early COVID-19 studies were targeted at adult patients, and data concerning children and adolescents are limited.

- Clinical manifestations of COVID-19 are generally milder in the pediatric population compared with adults.

- Hospitalization for COVID-19 affects mostly infants, toddlers, and children with pre-existing comorbidities.

What this study adds

[?] This study comprehensively characterizes a large international cohort of pediatric COVID-19 patients, and almost 2 million with previous seasonal influenza across 5 countries.

[3. Although uncommon, pneumonia, acute respiratory distress syndrome (ARDS) and multisystem inflammatory syndrome (MIS-C) were more frequent in children and adolescents diagnosed with COVID-19 than in those with seasonal influenza.

[? Dyspnea, bronchiolitis, anosmia and gastrointestinal symptoms were more frequent in COVID-19, and could help to differentiate pediatric COVID-19 from influenza.

[2] A plethora of medications were used during the management of COVID-19 in children and adolescents, with great heterogeneity in the use of antiviral therapies as well as of adjunctive therapies. 


\section{ABSTRACT \\ Objectives}

To characterize the demographics, comorbidities, symptoms, in-hospital treatments, and health outcomes among children/adolescents diagnosed or hospitalized with COVID-19. Secondly, to describe health outcomes amongst children/adolescents diagnosed with previous seasonal influenza.

\section{Design}

International network cohort.

\section{Setting}

Real-world data from European primary care records (France/Germany/Spain), South Korean claims and US claims and hospital databases.

\section{Participants}

Diagnosed and/or hospitalized children/adolescents with COVID-19 at age $<18$ between January and June 2020; diagnosed with influenza in 2017-2018.

\section{Main outcome measures}

Baseline demographics and comorbidities, symptoms, 30-day in-hospital treatments and outcomes including hospitalization, pneumonia, acute respiratory distress syndrome (ARDS), multi-system inflammatory syndrome (MIS-C), and death.

\section{Results}

A total of 55,270 children/adolescents diagnosed and 3,693 hospitalized with COVID-19 and $1,952,693$ diagnosed with influenza were studied.

Comorbidities including neurodevelopmental disorders, heart disease, and cancer were all more common among those hospitalized vs diagnosed with COVID-19. The most common COVID-19 symptom was fever. Dyspnea, bronchiolitis, anosmia and gastrointestinal symptoms were more common in COVID-19 than influenza.

In-hospital treatments for COVID-19 included repurposed medications $(<10 \%)$, and adjunctive therapies: systemic corticosteroids $(6.8 \%$ to $37.6 \%)$, famotidine $(9.0 \%$ to $28.1 \%)$, and antithrombotics such as aspirin ( $2.0 \%$ to $21.4 \%)$, heparin ( $2.2 \%$ to $18.1 \%)$, and enoxaparin $(2.8 \%$ to $14.8 \%)$.

Hospitalization was observed in $0.3 \%$ to $1.3 \%$ of the COVID-19 diagnosed cohort, with undetectable ( $\mathrm{N}<5$ per database) 30-day fatality. Thirty-day outcomes including pneumonia, ARDS, and MIS-C were more frequent in COVID-19 than influenza.

\section{Conclusions}

Despite negligible fatality, complications including pneumonia, ARDS and MIS-C were more frequent in children/adolescents with COVID-19 than with influenza. Dyspnea, anosmia and gastrointestinal symptoms could help differential diagnosis. A wide range of medications were used for the inpatient management of pediatric COVID-19. 
medRxiv preprint doi: https://doi.org/10.1101/2020.10.29.20222083; this version posted October 30, 2020. The copyright holder for this preprint (which was not certified by peer review) is the author/funder, who has granted medRxiv a license to display the preprint in perpetuity.

It is made available under a CC-BY 4.0 International license .

\section{INTRODUCTION}

Since January 2020, a growing number of infections by the severe acute respiratory syndrome coronavirus 2 (SARS-CoV-2) has led to an unprecedented pressure on healthcare systems worldwide. As of $14^{\text {th }}$ of October 2020, there were 38,002,699 confirmed cases of coronavirus disease 2019 (COVID-19) and 1,083,234 deaths according to the World Health Organization (WHO) Dashboard. COVID-19 affects all age groups, including the pediatric population, which represents $3.7 \%$ of reported cases [1].

With day-care centers and schools re-opening in many parts of the world despite high levels of community transmission, it is of considerable importance to elucidate the baseline clinical features and health outcomes seen in children/adolescents (aged below 18 years) diagnosed with COVID-19 during the first wave of the pandemic. The pediatric presentation of COVID-19 reported to date ranges from completely asymptomatic but test positive to symptoms of acute upper respiratory tract infection and rarely various severe manifestations.[2] Clinical manifestations of COVID-19 are generally milder in the pediatric population,[3] with better outcomes and lower mortality rates than adults.[4] Nevertheless, there is evidence of children/adolescents with COVID-19 requiring hospitalization and intensive care unit (ICU)-level care. Reports from the United States (US) revealed that a low number of pediatric COVID-19 cases were hospitalized (5.7\%), mainly among adolescents aged 15-17 years (32\%) and those with underlying comorbidities such as chronic lung disease (including asthma), cardiovascular disease, or immunosuppression. [5] These findings are in line with a report on pediatric COVID-19 patients ( $<16$ years old) in China, where only $1.8 \%$ were admitted to the ICU.[6] A study conducted in 25 European countries, on the other hand, found that in a sample of 582 children/adolescents aged below 18 years, $63 \%$ were hospitalized.[7]

To date, most clinical guidelines recommend supportive care as the mainstay of therapy in children [8-10], but there is little data to recommend or reject the use of specific immunomodulatory drugs or antivirals. It also remains to be elucidated whether children/adolescents show a different clinical presentation.[11] We conducted a literature review for articles published in PubMed and Medrxiv (preprints) between December 2019 and June 2020 that reported on patients with a confirmed COVID-19 diagnosis. Of the 1320 studies that met the inclusion criteria, only 79 studies were on children/adolescents, most of which (63\%) were local case reports or case series. This compellingly demonstrates a large remaining gap in existing efforts to define the characteristics of the pediatric population in a real-world setting at a large scale.

In this study, we aimed to describe the demographics, comorbidities, symptoms, in-hospital treatments, and health outcomes of children/adolescents diagnosed or hospitalized with COVID-19, using electronic health records (EHRs) and health claims databases across the US, Europe and Asia. In addition, we compared these cohorts with children/adolescents diagnosed with seasonal influenza in 2017-2018 as a benchmark.

\section{METHODS}

\section{Study design, setting and data sources}

This study is part of the Characterizing Health Associated Risks, and Your Baseline Disease In SARSCOV-2 (CHARYBDIS) study, a large-scale multinational cohort study using routinely-collected primary care and hospital EHRs, hospital billing data and insurance claims data from the US, Europe (the Netherlands, Spain, the UK, Germany and France) and Asia (South Korea and China). 
medRxiv preprint doi: https://doi.org/10.1101/2020.10.29.20222083; this version posted October 30, 2020. The copyright holder for this preprint (which was not certified by peer review) is the author/funder, who has granted medRxiv a license to display the preprint in perpetuity.

It is made available under a CC-BY 4.0 International license.

From the nineteen databases contributing data to CHARYBDIS, only those with data on patients below the age of 18 years with a clinical diagnosis of COVID-19 or a SARS-CoV-2 positive test between January and June 2020 were included. A cohort of children/adolescents diagnosed with seasonal influenza in 2017-2018 was included for comparison.

To be included in the study, databases had to have a minimum of 140 children/adolescents (aged below 18 years). This cut-off was deemed necessary to estimate with sufficient precision (confidence interval width of $\pm 5 \%$ ) the prevalence of a previous condition or 30-day risk of an outcome affecting $10 \%$ of the study population. Data results for this paper were extracted from CHARYBDIS results on the $22^{\text {nd }}$ of September 2020. Figure 1 represents the selection process of the databases for this study. Eleven databases fulfilled the inclusion criteria: STARR-OMOP (US)[12], CU-AMC HDC (US), HealthVerity (US), CUIMC (US), OPTUM-EHR (US), Premier (US), IQVIA-OpenClaims (US), IQVIA-LPD France (France), IQVIA-DA Germany (Germany), SIDIAP (Spain)[13], HIRA (South Korea). Among these, five databases contributed to the hospitalized cohort: Premier, OPTUM-EHR, IQVIAOpenClaims, CUIMC, HIRA. A more detailed description of the included data sources is available in Supplementary Table 1.

\section{Study participants and follow-up}

Two non-mutually exclusive cohorts were included: 1) children/adolescents with COVID-19 diagnosis or a SARS-CoV-2 positive test (index date was the first of the two events), 2) children/adolescents hospitalized (index date was hospitalization date), with COVID-19 diagnosis or a SARS-CoV-2 positive test 21 days before or after hospitalization date. A similar diagnosed cohort of children/adolescents with seasonal influenza diagnosis or positive influenza test in 2017-2018 was also included. Study participants could contribute information to all cohorts (diagnosed or hospitalized with COVID-19, or diagnosed with influenza). Individuals diagnosed with COVID-19 could be part of the hospitalized cohort if COVID-19 was diagnosed during or at the time or 21 days before hospitalization. Cohort participants were followed in each cohort from the index date to the earliest of death, end of the observation period, or 30 days after. The codes used to identify COVID-19 are described in Supplementary Table 2 . In order to describe history of comorbidities, only participants with at least 365 days of prior observation before index date were included. Children below age one were excluded from the cohorts requiring 365 days of prior observation.

\section{Baseline characteristics, symptoms, drug use and outcomes of interest}

Baseline information on age at index date and conditions up to 1 year before index date were identified. Conditions were ascertained based on the Systematized Nomenclature of Medicine Clinical Terms (SNOMED CT) hierarchy, with all descendant codes included. Detailed definitions of each condition can be consulted in Supplementary Table 2.

Symptoms recorded at index date included fever, cough, dyspnea, malaise or fatigue, myalgia, anosmia or hyposmia or dysgeusia, gastrointestinal tract symptoms, diarrhea, vomits and nausea. All drugs prescribed/dispensed during the 30-days follow-up after the index date were ascertained. Individual medications were categorized using Anatomical Therapeutic Chemical (ATC) groupings. For the study of medications potentially used for COVID-19, we assessed all medications included in at least two randomized controlled trials [14]. The list was further enriched with suggestions from key stakeholders including regulatory agencies, key opinion leaders, and pharma industry. Medicines 
of interest were grouped into: 1) repurposed medications- those with alternative indications but believed to be efficacious as antivirals, 2) adjuvant therapies - used allegedly for the treatment or prevention of COVID-19 complications [15]. All conditions and medications and additional time windows (a month prior and on index date) are reported in full and are available in an interactive website: https://data.ohdsi.org/Covid19CharacterizationCharybdis/.

The 30-day outcomes described in the diagnosed cohorts included hospitalization, death, pneumonia, and multi-system inflammatory syndrome in children (MIS-C, Kawasaki disease, or toxic shock syndrome). In the hospitalized cohorts, we additionally report sepsis, total cardiovascular disease events, acute respiratory disease syndrome (ARDS), cardiac arrhythmia, and bleeding. The definition of each outcome is provided in Supplementary Table 2.

\section{Statistical analyses}

All data were standardized to the Observational Medical Outcomes Partnership (OMOP) Common Data Model (CDM).[16] A common analytical code for the CHARYBDIS study was developed for the OHDSI Methods library which was run locally in each database. Only aggregate results from each database were publicly shared. The CHARYBDIS protocol and source code can be found at https://github.com/ohdsi-studies/Covid19CharacterizationCharybdis. Results were extracted from CHARYBDIS on October 1st 2020.

Demographics, history of comorbidities, symptoms and outcomes were summarized as proportions, calculated by dividing the number of people within a given category by the total number of people. The proportion of users of each medication was determined for the hospitalized children/adolescents as the percentage of subjects who had >=1 day during the time window overlapping with a drug use period for each medication or drug class of interest. Utilization of repurposed and adjuvant drugs up to 30 days after admission was described.

The distribution of conditions a year prior to index, symptoms at index, outcomes and medications up to 30 days post-index date in COVID-19 diagnosed cohort were compared to the hospitalized COVID-19 or the diagnosed influenza cohorts. Standardized mean differences (SMD) were calculated when comparing the characteristics of study cohorts.

We performed a sensitivity analysis describing characteristics of cases with no prior observation time in order to understand the impact of lack of prior observation time in the results.

We used R version 3.6 (R Foundation for Statistical Computing, Vienna, Austria) for data visualization. All the data partners obtained Institutional Review Board (IRB) approval or exemption to conduct this study, as required.

\section{RESULTS}

A total of 55,270 children/adolescents diagnosed (3,693 hospitalized) with COVID-19, and 1,956,358 diagnosed with seasonal influenza were included. Data were obtained from 5 US hospital EHR databases (STARR-US [with the pediatric population representing 3.9\% of all COVID-19 cases in this database], CU-AMC-HDC-US [2.6\% of all COVID-19 cases], CUIMC-US [4.1\% of all COVID-19 cases], OPTUM-EHR-US [4.4\% of all COVID-19 cases] and PREMIER-US [3.9\% of all COVID-19 cases]), 3 European primary care records databases (IQVIA-LPD-France [4.0\% of all COVID-19 cases], IQVIA-DAGermany [7.1\% of all COVID-19 cases], SIDIAP-Spain [3.7\% of all COVID-19 cases]), and 2 US (HealthVerity-US [4.6\% of all COVID-19 cases], IQVIA-OpenClaims-US [2.9\% of all COVID-19 cases]) 
and 1 Asian claims databases (HIRA South Korea [3.3\% of all COVID-19 cases]). Up to at least 1 year of pre-index observation time was available only in CU-AMC-HDC-US, OPTUM-EHR-US, SIDIAP-Spain, and IQVIA-OpenClaims-US. Figure 1 shows a flowchart outlining the reasons for exclusion of additional 8 data sources available in CHARYBDIS.

\section{Demographics}

Age at diagnosis of COVID-19 varied across regions. In SIDIAP-Spain, CUIMC-US and STARR-US the majority of children with COVID-19 were diagnosed at ages 0 to 4 years (around one third), while the proportion of children from 0 to 4 years was only $11.4 \%$ and $11.6 \%$ in IQVIA-LPD-France and CUIMCUS, respectively. More consistently, most of the hospital admissions were seen in the younger groups (0-4 years), e.g. $40.6 \%$ of those hospitalized in IQVIA-OpenClaims-US, and $76.2 \%$ in PremierUS. Male gender was more common in all databases except for IQVIA-LPD-France ( $46.8 \%$ male) and STARR-US (49.2\%) (Table 1).

\section{Comorbidities}

Assessed in the year before index date, asthma was the most common baseline comorbidity in patients diagnosed with COVID-19, affecting 10.1\% (SIDIAP-Spain) to $33.6 \%$ (IQVIA-OpenClaims-US), followed by obesity (from $1.9 \%$ in IQVIA-LPD-France to $19.4 \%$ in OPTUM-EHR-US). We observed a high prevalence of congenital malformation(s) $(7.9 \%$ of those diagnosed in IQVIA-OpenClaims-US to $10.8 \%$ in SIDIAP-Spain), neurodevelopmental disorders (1.0\% of those diagnosed in IQVIA-LPDFrance to $8.8 \%$ in IQVIA-OpenClaims-US), heart disease (1.2\% in IQVIA-LPD-France to $13.1 \%$ in IQVIAOpenClaims-US), type 1 diabetes mellitus (0.2\% in SIDIAP-Spain to $0.5 \%$ in IQVIA-OpenClaims-US), cancer $(0.3 \%$ in SIDIAP-Spain to $4 \%$ in OPTUM-EHR-US), and chromosomal disorder(s) $(0.4 \%$ in SIDIAP-Spain to $1.3 \%$ in IQVIA-OpenClaims-US). All of these were more common amongst hospitalized children/adolescents with COVID-19 as compared to the diagnosed with COVID-19 cohort (SMD>0.1): $38.8 \%$ asthma, $13.1 \%$ obesity, $37.0 \%$ heart disease $(5.1 \%$ congenital heart disease), $13.2 \%$ cancer, $5.8 \%$ chromosomal disorder(s), $22.7 \%$ congenital malformation(s), and $4.1 \%$ prematurity in IQVIA-OpenClaims-US (Figure 2).

\section{Symptoms}

Figure 3a shows recorded symptoms at index date for diagnosed vs hospitalized COVID-19 patients while Figure $3 \mathrm{~b}$ displays symptoms of COVID-19 vs influenza cohorts. The most common reported symptom in COVID-19 was fever, seen in $4.8 \%$ (SIDIAP-Spain) to $26.4 \%$ (CUIMC-US) of diagnosed cases, and higher (up to $28.1 \%$ in CUIMC-US) among hospitalized cases. Second most common was cough, recorded in $4.7 \%$ (SIDIAP-Spain) to $14.5 \%$ (Premier-US) amongst the diagnosed, and lower (e.g. $2.8 \%$ in Premier-US) in hospitalized children/adolescents. Bronchiolitis was recorded in $0.5 \%$ (SIDIAP-Spain) to 3.1\% (IQVIA-OpenClaims-US) of the diagnosed, and higher (up to $11.9 \%$ in Optum EHR-US) in the hospitalized. Gastrointestinal tract symptoms were also common at index date, recorded in $0.5 \%$ (HealthVerity-US) to $12.5 \%$ (SIDIAP-Spain) in diagnosed, and up to $15.0 \%$ (OptumEHR-US) among hospitalized. Anosmia was $<=1 \%$ in all participating databases, both in diagnosed and admitted COVID-19 patients. Compared to influenza, COVID-19 diagnosed children/adolescents had less frequently reported symptoms in most databases, with the only exceptions of: dyspnea (e.g. $4.1 \%$ in COVID-19 vs $0.4 \%$ in influenza in IQVIA-OpenClaims-US), bronchiolitis (e.g. $3.1 \%$ in COVID-19 vs $0.2 \%$ in influenza in IQVIA-OpenClaims-US), anosmia/hyposmia/dysgeusia (e.g. $0.5 \%$ in COVID-19 vs $0.0 \%$ in influenza in IQVIA-OpenClaims-US), and gastrointestinal tract symptoms (e.g. $4.9 \%$ in COVID-19 vs $3.4 \%$ in influenza in IQVIA-OpenClaims-US).

\section{In-hospital treatments}


Use of drugs during hospital admission for COVID-19 amongst children/adolescents is reported in Figures $4 \mathrm{a}$ (repurposed) and $4 \mathrm{~b}$ (adjunctive therapies), based on data from CUIMC-US, OPTUM-EHRUS, Premier-US, and HIRA-South Korea. Repurposed treatments were not commonly used $<10 \%$ in all databases), with lopinavir-ritonavir used in $<6 \%$ in HIRA-South Korea but not in US databases, azithromycin from $4 \%$ to $6 \%$ in all databases, hydroxychloroquine in $1.5 \%$ (Premier-US) to just above $4 \%$ (OPTUM-EHR-US), and oseltamivir only in the US, from $<1 \%$ in Premier-US to just over $5 \%$ in CUIMC-US.

Adjunctive therapies were more common, with systemic corticosteroids used in $6.8 \%$ (HIRA-South Korea) to $37.6 \%$ (CUIMC-US). Famotidine was the second most common adjunctive treatment, used in $9.0 \%$ (OPTUM-EHR-US) to $28.1 \%$ (CUIMC-US). Concomitant antithrombotic therapy was also common in the US but not in HIRA-South Korea (no use reported), including aspirin (2.0\% in PremierUS to $21.4 \%$ in CUIMC-US), heparin (2.2\% in Premier-US to $18.1 \%$ in CUIMC-US), and enoxaparin (2.8\% in Premier-US to $14.8 \%$ in CUIMC-US). Antibiotics (ceftriaxone, amoxicillin, fluoroquinolones), vitamin ( $D$ and $C$ ) supplements, and immunoglobulins were also used with high variability between the contributing databases.

\section{Health outcomes}

Outcomes in the 30-day period following the diagnosis of COVID-19 and hospitalization with COVID19 are summarized in Table 1 and Figure 5a. Hospitalization was observed in a low proportion $(0.3 \%$ in HealthVerity-US, $1.4 \%$ in SIDIAP-Spain) in the ambulatory/claims databases with testing and testing results data available; in $13.2 \%$ in IQVIA-OpenClaims-US; and more frequent $17.1 \%$ in OPTUM-EHR-US to $36.1 \%$ in Premier-US) in hospital EHR databases. Pneumonia was the most common complication, diagnosed in a wide range from $0.1 \%$ (HealthVerity-US) to $6.5 \%$ (IQVIAOpenClaims-US) of those diagnosed, and in $6.8 \%$ (HIRA-South Korea) to $20.3 \%$ (IQVIA-OpenClaimsUS) of those hospitalized with COVID-19. ARDS was the most common in-hospital outcome, affecting 8.1\% (CUIMC-US) to $22.7 \%$ (Premier-US) of those hospitalized with COVID-19. Sepsis during admission was observed in $<2 \%$ ( $\mathrm{N}<5$; HIRA-South Korea) to $9.4 \%$ in Premier-US. Other less common outcomes are reported in Table 1 . MIS-C was rare, and seen only in $<0.1 \%$ ( $\mathrm{N}<5$; SIDIAP-Spain) to $0.3 \%$ (IQVIA-OpenClaims-US).

A comparison of outcomes in those diagnosed with COVID-19 vs those diagnosed with influenza in previous years is depicted in Figure 5b. Hospitalization rates were higher for COVID-19 vs influenzadiagnosed children/adolescents (e.g. $13.2 \%$ vs $0.9 \%$ in IQVIA-OpenClaims-US, $33.2 \%$ vs $7.4 \%$ in CUIMC-US, $30.8 \%$ vs $3.7 \%$ in STARR-US). Similarly, pneumonia was more common in COVID19diagnosed participants (e.g. $3.1 \%$ vs $0.7 \%$ in SIDIAP-Spain, $6.5 \%$ vs $2.4 \%$ in IQVIA-OpenClaims-US); and so was ARDS (e.g. $2.5 \%$ vs $0.1 \%$ in IQVIA-OpenClaims-US, $3.3 \%$ vs $0.7 \%$ in CUIMC-US) and despite rare- MIS-C (e.g. $0.3 \%$ vs $0.0 \%$ in IQVIA-OpenClaims-US, $3.1 \%$ vs $<0.2 \%$ in CUIMC-US). Other outcomes had more similar risks in both viral infections (see Figure $5 \mathrm{~b}$ and Supplementary Table 3).

In a sensitivity analysis, we replicated the analyses including participants who had no prior history available in their EHRs (Supplementary Table 4). Differences in symptoms or outcomes were modest, however it demonstrated the expected incompleteness in prevalent comorbidity.

\section{DISCUSSION}

This study comprehensively reports on the largest cohort of children/adolescents with COVID-19 to date, covering more than 55,000 children/adolescents diagnosed and almost 3,700 hospitalized with 
medRxiv preprint doi: https://doi.org/10.1101/2020.10.29.20222083; this version posted October 30, 2020. The copyright holder for this preprint (which was not certified by peer review) is the author/funder, who has granted medRxiv a license to display the preprint in perpetuity.

It is made available under a CC-BY 4.0 International license .

COVID-19 in 5 countries from North America, Europe, and Asia. We also studied a cohort of almost two million children/adolescents diagnosed with seasonal influenza in previous years for comparison.

Overall, most cases of COVID-19 diagnosis and related hospitalizations were seen amongst infants and toddlers aged $<4$ years old, predominantly of male sex. Children/adolescents hospitalized with COVID-19 had a higher prevalence of comorbidities than the overall cohort of those diagnosed with COVID-19, including asthma, obesity, heart disease, cancer, chromosomal disorder(s), and congenital malformation(s). The most commonly observed symptoms were fever and cough, while dyspnea, bronchiolitis, anosmia and gastrointestinal tract symptoms were more common in children/adolescents with COVID-19 than with seasonal influenza, and may aid on the differentiation of COVID-19 from other viral infections.

The drug utilization analysis suggests little use of repurposed drugs and a substantial use of adjunctive therapies among children/adolescents. A high heterogeneity in the use of these drugs across the participating databases underlies differences in COVID-19 management practices across countries among young children/adolescents.

A low proportion of children/adolescents diagnosed with COVID-19 required hospital admission amongst those diagnosed in primary care or outpatient settings (e.g. 1.4\% amongst those seen initially in primary care/outpatient), but higher rates (15\% to $36 \%$ ) among those diagnosed in hospital settings.

Hospitalization rates were between 5- and 13-fold higher amongst those children/adolescents diagnosed with COVID-19 vs. those with seasonal influenza in previous years. Fortunately, 30-day fatality following a COVID-19 diagnosis or hospitalization was low: less than 5 children/adolescents died in any of the contributing databases. Respiratory complications (pneumonia and ARDS) were over-represented among children/adolescents diagnosed with COVID-19 compared with seasonal influenza, as was MIS-C. Further outcomes demonstrated similar rates across both cohorts.

\section{Comparison with other studies}

The proportion of children/adolescents under 18 years of age from all observed COVID-19 cases in each database varied from $2.6 \%$ in CU-AMC HDC-US to $7.1 \%$ in IQVIA-DA-Germany. These values are higher than what has been previously reported in other studies from China (2\%) [17], Spain (2\%) [18], the US (1.7\%) [5], or the UK (0.9\%) [19], but in line with the WHO dashboard which reported that children below the age of 14 years old accounted for $3.7 \%$ of all COVID-19 cases [1], or the Australian Health Protection Agency which has reported that children/adolescents below the age of 19 years accounted for $4 \%$ of confirmed COVID-19 cases in Australia.[20]

Asthma and obesity were the most common baseline comorbidities in children/adolescents with COVID-19; this was expected, and is in keeping with disease prevalence among a general pediatric population. [21] More strikingly, we observed a high prevalence of conditions that are relatively rare in children/adolescents, including congenital malformation/s, neurodevelopmental disorders, heart disease, type 1 diabetes mellitus, cancer, and chromosomal disorder/s. These conditions were more frequent amongst hospitalized children/adolescents with COVID-19 than the overall cohort of those diagnosed with COVID-19. This is in line with previous studies suggesting that children with comorbidity history have higher risk of critical care admission $[19,22]$.

Despite the great variability in the reporting of symptoms across databases, we found that the most commonly identified symptoms in children/adolescents with COVID-19 were consistently fever, 
cough, dyspnea, and gastrointestinal tract symptoms which are in line with previous studies $[7,19,22]$. However, the frequency of reported symptoms in our study is generally lower than what has been previously reported in the pediatric literature $[7,19,22]$, suggesting an underestimation in the register of symptoms in the form of structured data in busy actual care settings. An important finding is that COVID-19 diagnosed children/adolescents presented with higher rates of dyspnea, anosmia, and gastrointestinal symptoms than children with seasonal influenza. This information is clinically relevant for differential diagnosis between COVID-19 and influenza among children/adolescents.

We observed great heterogeneity across countries in the use of in-hospital treatments among children/adolescents with COVID-19, which is in line with previous studies in adults [23]. Our analysis suggests little use of antiviral therapies overall, with about $5 \%$ of children/adolescents hospitalized with COVID-19 using lopinavir/ritonavir in South Korea (but none in the US); a variable proportion of use of oseltamivir ( $1 \%$ to $5 \%$ ) in the US (but none in South Korea); a $4-5 \%$ of use of azithromycin, and limited use of hydroxychloroquine, ranging from $1.5 \%$ to around $4 \%$ in both countries. These values are lower than what we previously reported in adults (e.g. use of hydroxychloroquine was $57.9 \%$ in the overall population vs. $1.5 \%$ in children/adolescents in Premier-US) [23], but in line with recent European cohort studies in hospitalized children/adolescents with COVID-19. A study in the UK reported that $6 \%(38 / 591)$ of hospitalized children/adolescents with COVID-19 received antiviral drugs (30 received acyclovir, 7 received remdesivir, and 3 received chloroquine or hydroxychloroquine) [19], while a study in 25 European countries including 582 children/adolescents found that $7 \%$ were treated with hydroxychloroquine, $3 \%$ with remdesivir, $1 \%$ with lopinavir-ritonavir, $1 \%$ with oseltamivir.[7] In contrast, we observed substantial use of different adjunctive therapies; corticosteroids were used in $25-35 \%$ in the US but $7 \%$ in South Korea. Famotidine ( 2 to $20 \%$ ), aspirin (10 to $30 \%$ ) and vitamin D ( 2 to $15 \%$ ) were used in the US but not in South Korea. Antibiotics were also commonly used, with ceftriaxone and amoxicillin amongst the most commonly prescribed. This is consistent with the previous study in in UK where antibiotics were given to $69 \%$ (415/601) of hospitalized children with COVID-19.[19]

It is reassuring that occurrence of severe outcomes during the 30 days after diagnosis of COVID-19 was rare in our study, which is in line with previous studies $[7,18,19,22]$. MIS-C was relatively uncommon, affecting $0.5 \%-3.1 \%$ of all diagnosed cases, but up to $0.9 \%-7.6 \%$ of those hospitalized with COVID-19. These results are in line with previous studies from Europe and the US which have suggested that COVID-19 may be associated with MIS-C in children.[24-26] A separate cohort study found recently that $11 \%$ of children with COVID-19 admitted to hospitals in the UK developed MISC.[19] These findings are of special relevance given the severity of this condition. Our results also confirmed MIS-C might be specifically related to COVID-19, since it was much less common in patients hospitalized with influenza. Overall, all outcomes were more frequent in children/adolescents with COVID-19 diagnosis than those with a diagnosis of seasonal influenza in 2017-2018, suggesting more severe disease prognosis in children with COVID-19 than influenza. Future research is needed to characterize and determine the long-term outcomes of children/adolescents affected with COVID-19.

\section{Strengths and limitations}

This study has some limitations. First, this study is descriptive in nature. The observed differences between groups should therefore not be interpreted as causal effects. Second, our results are based on secondary data from electronic records collected for administrative and clinical management purposes and re-used for research which may affect the completeness of data recorded and may have erroneous entries, leading to potential misclassification. Such incompleteness could be 
differential in some instances (e.g. hospital vs primary care settings) and risk information bias for the proposed comparisons. Moreover, variability in coding practices and the heterogeneity in healthcare settings inherent to this study may account for some of the observed variability in the prevalence of comorbidities, symptoms and outcomes. Hospital admissions are also variably recorded in the analyzed databases. The under-reporting of symptoms observed in these data is a key finding of this study, and should be taken into consideration in previous and future similar reports from 'real-world' cohorts. Our analysis of mortality is similarly subject to differences by database. For example, data on inpatient deaths are more complete while primary care or outpatient death events are typically imported into a given database from a national or local death register. Finally, the currently available data is restricted to the first six months of 2020 coinciding with the peak of the COVID-19 peak in the studied countries. As data accumulates over time future updates of the results will provide the opportunity to study more recent cohorts of COVID-19 patients, who seem to have a better prognosis overall compared to those diagnosed in the first half of the year.

This study is unique as our approach to characterizing children with an international scope allows for a wide range of variation in healthcare systems and policies against the COVID-19 pandemic. This enables a more complete understanding of the implications of the pandemic for different countries and regions in scope of an international comparison. It also poses a layer of heterogeneity that needs to be considered in the interpretation of our findings, opening a window for new research questions that need to be addressed; particularly around the public health approach for controlling the pandemic spread and severity in children/adolescents and overall. This study represents, to our knowledge, the largest cohort study on pediatric COVID-19 to date, and the only study to provide a comparison with children/adolescents with seasonal influenza in 2017-2018. Our data confirm low rates of complications in children with COVID-19, with severe cases clustering amongst children with previous comorbidities. Despite the large sample size available, MIS-C appears rare.

\section{Conclusions}

COVID-19 affects children/adolescents of all ages but severe outcomes are reassuringly uncommon. There is variability across healthcare systems in different regions of America, Asia and Europe that may explain the observed differences in the epidemiology and clinical management of the disease as well as observed outcomes. Despite negligible fatality, complications including pneumonia, ARDS and MIS-C are more frequent in children/adolescents with COVID-19 than with influenza. Dyspnea, anosmia and gastrointestinal symptoms could help differential diagnosis. 


\section{Ethical approval}

All the data partners received Institutional Review Board (IRB) approval or exemption. STARR-OMOP had approval from IRB Panel \#8 (RB-53248) registered to Leland Stanford Junior University under the Stanford Human Research Protection Program (HRPP). The use of VA data was reviewed by the Department of Veterans Affairs Central IRB, was determined to meet the criteria for exemption under Exemption Category 4(3), and approved for Waiver of HIPAA Authorization. The IRB number for use of HIRA data was AJIB-MED-EXP20-065. The research was approved by the Columbia University Institutional Review Board as an OHDSI network study. The use of SIDIAP was approved by the Clinical Research Ethics Committee of the IDIAPJGol (project code: 20/070-PCV). The use of CPRD was approved by the Independent Scientific Advisory Committee (ISAC) (protocol number 20_059RA2). The use of IQVIA-OpenClaims, IQVIA-LPD-France, and IQVIA-DA-Germany were exempted from IRB approval.

\section{Funding}

The European Health Data \& Evidence Network has received funding from the Innovative Medicines Initiative 2 Joint Undertaking (JU) under grant agreement No 806968. The JU receives support from the European Union's Horizon 2020 research and innovation programme and EFPIA. This research received partial support from the National Institute for Health Research (NIHR) Oxford Biomedical Research Centre (BRC), US National Institutes of Health, US Department of Veterans Affairs, Janssen Research \& Development, and IQVIA. The University of Oxford received funding related to this work from the Bill \& Melinda Gates Foundation (Investment ID INV-016201 and INV-019257). The IDIAPJGol received funding from the Health Department from the Generalitat de Catalunya with a grant for research projects on SARS-CoV-2 and COVID-19 disease organized by the Direcció General de Recerca i Innovació en Salut. DPA received funding from the NIHR Academy in the form of an NIHR Senior Research Fellowship. WURA reports funding from the NIHR Oxford Biomedical Research Centre (BRC), Aziz Foundation, Wolfson Foundation, and the Royal College Surgeons of England. No funders had a direct role in this study. DRM is supported by a Wellcome Trust Clinical Research Development Fellowship (Grant 214588/Z/18/Z). The views and opinions expressed are those of the authors and do not necessarily reflect those of the NIHR Academy, NIHR, Department of Veterans Affairs or the United States Government, NHS, or the Department of Health, England.

\section{Competing interest statement}

All authors have completed the ICMJE uniform disclosure form at www.icmje.org/coi disclosure.pdf and declare: DV reports personal fees from Bayer, outside the submitted work, and full-time employment at Bayer. AG reports personal fees from Regeneron Pharmaceuticals, outside the submitted work; and she a full-time employee at Regeneron Pharmaceuticals. GH reports grants from US National Library of Medicine, during the conduct of the study; grants from Janssen Research, outside the submitted work. AS reports personal fees from Janssen Research \& Development, during the conduct of the study; personal fees from Janssen Research \& Development, outside the submitted work. SF is an employee of Janssen, Research and Development, a subsidiary of Johnson \& Johnson. PR is an employee of Janssen Research and Development and shareholder of Johnson \& Johnson. KK and CR report being employees of IQVIA. MS reports grants from US National Institutes of Health, grants from Department of Veterans Affairs, during the conduct of the study; grants from IQVIA, personal fees from Janssen Research and Development, outside the submitted work. DPA reports grants and other from AMGEN, grants, non- 
financial support and other from UCB Biopharma, grants from Les Laboratoires Servier, outside the submitted work; and Janssen, on behalf of IMI-funded EHDEN and EMIF consortiums, and Synapse Management Partners have supported training programs organized by DPA's department and open for external participants. FN was an employee of AstraZeneca until 2019 and holds some AstraZeneca shares. The views expressed are those of the authors and do not necessarily represent the views or policy of the Department of Veterans Affairs or the United States Government. No other relationships or activities that could appear to have influenced the submitted work.

\section{Transparency declaration}

Lead authors affirm that the manuscript is an honest, accurate, and transparent account of the study being reported; that no important aspects of the study have been omitted; and that any discrepancies from the study as planned have been explained.

\section{Contributorship statement}

TDS, DV, KK, APU, PR, DPA conceived and designed the study. SLD, TF, KEL, MEM, KN, JDP, CGR, NHS, $\mathrm{PR}, \mathrm{KK}$ and TDS coordinated data contributions at their respective sites. AP, AGS, TF, SFB, JDP, KK and TDS analyzed the data; AP produced the figures and tables. TDS, AP, and DPA interpreted the data. TDS, DV, PC, DPA searched the literature and wrote the first draft. WURA, KS, OA, CA, MG, PI, LYHL, TMA, FN and HA reviewed the literature and the manuscript draft. All authors contributed to the revision of the first draft, reviewed and approved the final version of the manuscript.

\section{Acknowledgements}

We would like to acknowledge the patients who suffered from or died of this devastating disease, and their families and carers. We would also like to thank the healthcare professionals involved in the management of COVID-19 during these challenging times, from primary care to intensive care units.

\section{PPI statement}

This research was done without patient involvement. Patients were not invited to comment on the study design and were not consulted to develop patient relevant outcomes or interpret the results. Patients were not invited to contribute to the writing or editing of this document for readability or accuracy.

\section{Data sharing statement}

Analyses were performed locally in compliance with all applicable data privacy laws. Although the underlying data is not readily available to be shared, authors contributing to this paper have direct access to the data sources used in this study. All results (e.g. aggregate statistics, not presented at a patient-level with redactions for minimum cell count) are available for public inquiry. These results are inclusive of site-identifiers by contributing data sources to enable interrogation of each contributing site. All analytic code and result sets are made available at: https://github.com/ohdsistudies/Covid19CharacterizationCharybdis 
medRxiv preprint doi: https://doi.org/10.1101/2020.10.29.20222083; this version posted October 30, 2020. The copyright holder for this preprint (which was not certified by peer review) is the author/funder, who has granted medRxiv a license to display the preprint in perpetuity.

It is made available under a CC-BY 4.0 International license.

\section{Dissemination declaration}

We will disseminate the findings of this study to all departments at author-affiliated institutions. In addition, we will further disseminate the findings of this study through press releases, social media, and on institutional web sites upon publication. 
medRxiv preprint doi: https://doi.org/10.1101/2020.10.29.20222083; this version posted October 30, 2020. The copyright holder for this preprint (which was not certified by peer review) is the author/funder, who has granted medRxiv a license to display the preprint in perpetuity.

It is made available under a CC-BY 4.0 International license .

\section{REFERENCES}

1. World Health Organization (WHO) [Internet]. WHO Coronavirus Disease (COVID-19) Dashboard [cited 2020 Sep 19]. Available from: https://covid19.who.int/

2. Dong $\mathrm{Y}, \mathrm{Mo} \mathrm{X}, \mathrm{Hu} \mathrm{Y}$, et al. Epidemiology of COVID-19 among children in China. Pediatrics. 2020;145(6):e20200702.

3. He J, Guo Y, Mao R, Zhang J. Proportion of asymptomatic coronavirus disease 2019: a systematic review and meta-analysis. J Med Virol. 2020;10.1002/jmv.26326.

4. Kim L, Whitaker M, O'Halloran A, et al. Hospitalization Rates and Characteristics of Children Aged $<18$ Years Hospitalized with Laboratory-Confirmed COVID-19 - COVID-NET, 14 States, March 1-July 25, 2020. MMWR Morb Mortal Wkly Rep. 2020;69(32):1081-1088.

5. CDC COVID-19 Response Team. Coronavirus Disease 2019 in Children - United States, February 12-April 2, 2020. MMWR Morb Mortal Wkly Rep. 2020;69(14):422-426.

6. Lu X, Zhang L, Du H, et al. SARS-CoV-2 infection in children. N Engl J Med. 2020; 382(17): 1663-1665.

7. Götzinger F, Santiago-García B, Noguera-Julián A et al. COVID-19 in children and adolescents in Europe: a multinational, multicentre cohort study. Lancet Child Adolesc Health. 2020; 4(9): 653-661.

8. World Health Organization (WHO) [Internet]. Clinical management of COVID-19 [updated 2020 May 27; cited 2020 Sep 27]. Available from:

https://www.who.int/publications/i/item/clinical-management-of-covid-19

9. Royal College of Paediatrics and Child Health (RCPCH) [Internet]. COVID-19 - guidance for paediatric services [updated 2020 Sep 24; cited 2020 Sep 27]. Available from: https://www.rcpch.ac.uk/resources/covid-19-guidance-paediatric-services

10. National Institutes of Health (NIH) [Internet]. COVID-19 Treatment Guidelines: Special Considerations in Children [updated 2020 Jun 11; cited 2020 Sep 27]. Available from: https://www.covid19treatmentguidelines.nih.gov/special-populations/children/

11. Mao LJ, Xu J, Xu ZH et al. A child with household transmitted COVID-19. BMC Infect Dis. 2020; 20: 329.

12. Datta $S$, Posada J, Olson $G$ et al. A new paradigm for accelerating clinical data science at Stanford Medicine. arXiv 2020.

13. Del Mar García-Gil M, Hermosilla E, Prieto-Alhambra D, et al. Construction and validation of a scoring system for the selection of high-quality data in a Spanish population primary care database (SIDIAP). Inform Prim Care. 2011; 19(3): 135-45.

14. Thorlund K, Dron L, Park J et al. A real-time dashboard of clinical trials for COVID-19. Lancet Digit Health. 2020; 2(6): e286-e287.

15. Sanders JM, Monogue ML, Jodlowski TZ, Cutrell JB. Pharmacologic treatments for coronavirus disease 2019 (COVID-19): A review. JAMA. 2020; 323(18):1824-1836.

16. Voss EA, Makadia R, Matcho A, et al. Feasibility and utility of applications of the common data model to multiple, disparate observational health databases. J Am Med Inform Assoc. 2015;22(3):553-64.

17. Wu Z, McGoogan JM. Characteristics of and Important Lessons From the Coronavirus Disease 2019 (COVID-19) Outbreak in China: Summary of a Report of 72 ?314 Cases From the Chinese Center for Disease Control and Prevention. JAMA. 2020;323(13):1239-42.

18. Tagarro A, Epalza C, Santos M et al. Screening and Severity of Coronavirus Disease 2019 (COVID-19) in Children in Madrid, Spain. JAMA Pediatr. 2020 Apr 8;e201346. 
19. Swann OV, Holden KA, Turtle L et al. Clinical characteristics of children and young people admitted to hospital with covid-19 in United Kingdom: prospective multicentre observational cohort study. BMJ. 2020;370:m3249

20. COVID-19 National Incident Room Surveillance Team. COVID-19, Australia: Epidemiology Report 12 (Reporting week to 23:59 AEST 19 April 2020). Commun Dis Intell (2018). 2020; 44. doi: $10.33321 /$ cdi.2020.44.36.

21. Peters U, Dixon A, Forno E. Obesity and Asthma. J Allergy Clin Immunol. 2018; 141(4): 11691179.

22. Parri N, Lenge $M$, Buonsenso D, Coronavirus Infection in Pediatric Emergency Departments (CONFIDENCE) Research Group. Children with Covid-19 in Pediatric Emergency Departments in Italy. N Engl J Med. 2020;383(2):187-90.

23. Prats-Uribe A, Sena AG, Lai LYH et al. Heterogeneity and temporal variation in the management of COVID-19: a multinational drug utilization study including 71,921 hospitalized patients from China, South Korea, Spain, and the United States of America. medRxiv 2020.09.15.20195545.

24. Verdoni L, Mazza A, Gervasoni A et al. An outbreak of severe Kawasaki-like disease at the Italian epicentre of the SARS-CoV-2 epidemic: an observational cohort study. Lancet. 2020;395(10239):1771-1778.

25. Riphagen S, Gomez X, Gonzalez-Martinez C, Wilkinson N, Theocharis P. Hyperinflammatory shock in children during COVID-19 pandemic. Lancet. 2020;395(10237):1607-1608.

26. Royal College of Paediatrics and Child Health (RCPCH) [Internet]. Guidance: Paediatric multisystem inflammatory syndrome temporally associated with COVID-19 [updated 2020 May 1; cited 2020 Sep 30]. Available at: https://www.rcpch.ac.uk/sites/default/files/202005/COVID-19-Paediatric-multisystem-\%20inflammatory\%20syndrome-20200501.pdf 
medRxiv preprint doi: https://doi.org/10.1101/2020.10.29.20222083; this version posted October 30, 2020. The copyright holder for this preprint (which was not certified by peer review) is the author/funder, who has granted medRxiv a license to display the preprint in perpetuity.

\section{It is made available under a CC-BY 4.0 International license .}

\section{TABLES AND FIGURES}

\section{Figure 1. Database selection process}

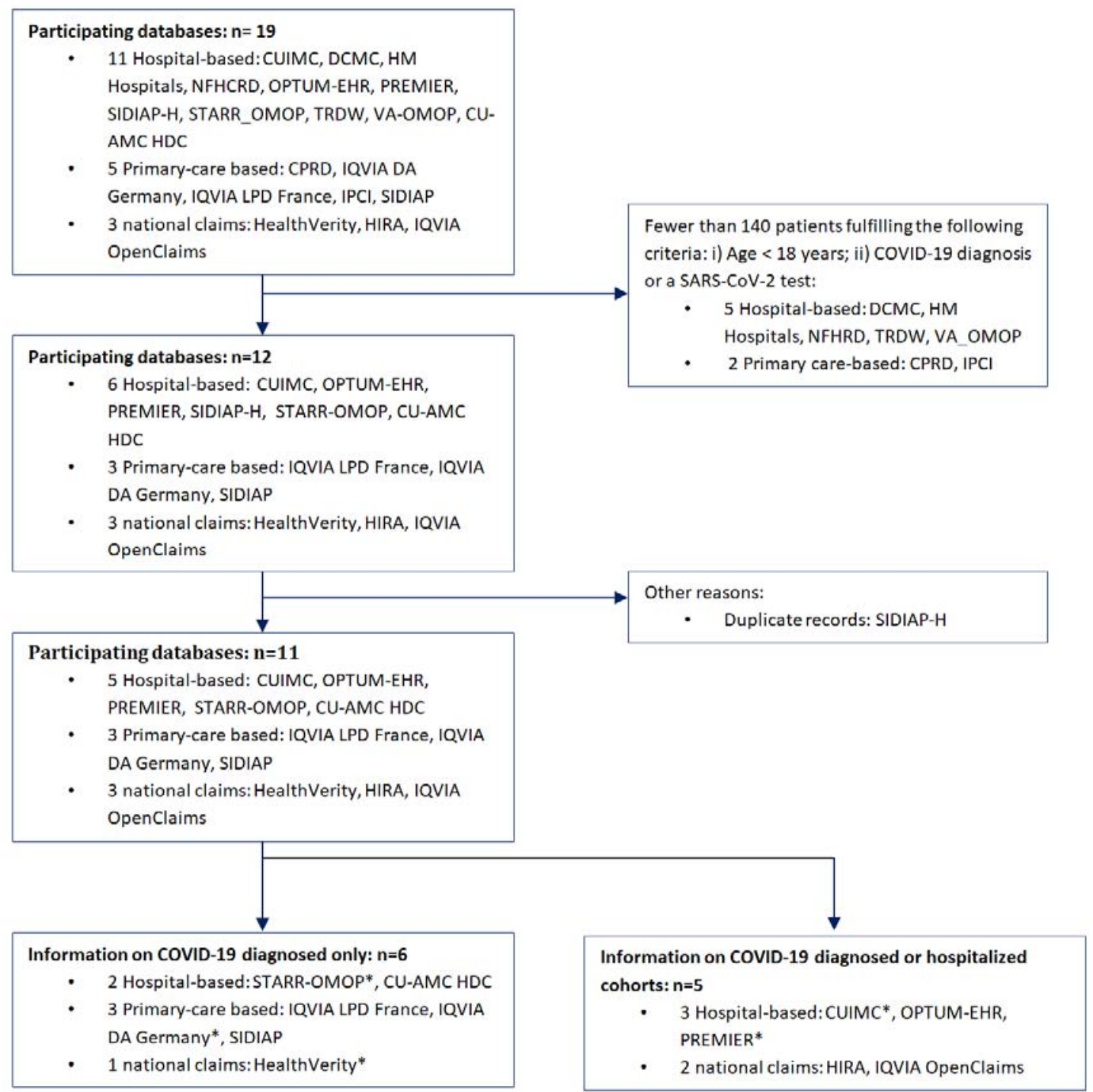

Colorado University Anschuz Medical Campus Health Data Compass (CU-AMC HDC), Columbia University Irving Medical Center (CUIMC), Clinical Practice Research Datalink (CPRD), Data Analyzer (DA), Daegu Catholic University Medical Center (DCMC), Health Insurance Review \& Assessment Service (HIRA), Integrated Primary Care Information (IPCI), Longitudinal Patient Data (LPD), Nanfang Hospital COVID19 Research Database (NFHCRD), Information System for Research in Primary Care (SIDIAP), STAnford medicine Research data Repository (STARR-OMOP), Tufts Research Data Warehouse (TRDW), Department of Veterans Affairs (VA-OMOP)

*No prior observation time available and therefore excluded from description of comorbidities. 
medRxiv preprint doi: https://doi.org/10.1101/2020.10.29.20222083; this version posted October 30, 2020. The copyright holder for this preprint (which was not certified by peer review) is the author/funder, who has granted medRxiv a license to display the preprint in perpetuity.

It is made available under a CC-BY 4.0 International license.

Table 1. Demographics, comorbidities, symptoms and outcomes among diagnosed and hospitalized COVID-19 children/adolescents (<18 years of age)*

\begin{tabular}{|c|c|c|c|c|c|c|c|c|c|c|c|c|c|c|c|}
\hline & \multicolumn{8}{|c|}{ At least 1 year of prior observation available } & \multicolumn{7}{|c|}{ No prior observation time available } \\
\hline & \multicolumn{5}{|c|}{ Diagnosed } & \multicolumn{3}{|c|}{ Hospitalized } & \multicolumn{5}{|c|}{ Diagnosed } & \multicolumn{2}{|c|}{ Hospitalized } \\
\hline & $\begin{array}{l}\text { SIDIAP } \\
\text { (Spain) }\end{array}$ & $\begin{array}{l}\text { IQVIA } \\
\text { LPD } \\
\text { (France } \\
\text { ) }\end{array}$ & $\begin{array}{l}\text { CU- } \\
\text { AMC } \\
\text { HDC } \\
\text { (US) }\end{array}$ & $\begin{array}{l}\text { IQVIA } \\
\text { OpenC } \\
\text { laims } \\
\text { (US) }\end{array}$ & $\begin{array}{l}\text { OPTU } \\
\text { M EHR } \\
\text { (US) }\end{array}$ & $\begin{array}{l}\text { HIRA } \\
\text { (South } \\
\text { Korea) }\end{array}$ & $\begin{array}{l}\text { IQVIA } \\
\text { OpenC } \\
\text { laims } \\
\text { (US) }\end{array}$ & $\begin{array}{l}\text { OPTUM } \\
\text { EHR } \\
\text { (US) }\end{array}$ & $\begin{array}{l}\text { CUIMC } \\
\text { (US) }\end{array}$ & $\begin{array}{l}\text { Premier } \\
\text { (US) }\end{array}$ & $\begin{array}{l}\text { IQVIA } \\
\text { DA } \\
\text { (Germ } \\
\text { any) }\end{array}$ & $\begin{array}{l}\text { HEALT } \\
\text { HVERI } \\
\text { TY } \\
\text { (US) }\end{array}$ & $\begin{array}{l}\text { STARR- } \\
\text { OMOP } \\
\text { (US) }\end{array}$ & $\begin{array}{l}\text { CUIMC } \\
\text { (US) }\end{array}$ & $\begin{array}{l}\text { Premie } \\
r \text { (US) }\end{array}$ \\
\hline & $n=4494$ & $n=695$ & $n=189$ & $\begin{array}{l}n=136 \\
21\end{array}$ & $\begin{array}{l}n=563 \\
9\end{array}$ & $n=251$ & $\begin{array}{l}n=189 \\
9\end{array}$ & $n=399$ & $n=425$ & $n=2560$ & $n=173$ & $\begin{array}{l}n=270 \\
38\end{array}$ & $n=185$ & $n=210$ & $n=934$ \\
\hline \multicolumn{16}{|l|}{ Age (years) } \\
\hline 00-04 & 31.2 & 11.4 & 11.6 & 27.0 & 18.8 & 17.1 & 40.6 & 33.3 & 60.2 & 63.0 & 22.5 & 16.6 & 38.4 & 57.1 & 76.2 \\
\hline $05-09$ & 28.6 & 23.2 & 4.0 & 25.1 & 21.4 & 16.3 & 26.9 & 20.8 & 15.5 & 13.2 & 26.0 & 20.5 & 16.8 & 15.2 & 10.4 \\
\hline $10-14$ & 24.0 & 36.3 & 23.3 & 25.5 & 26.0 & 33.5 & 17.8 & 21.8 & 13.2 & 11.7 & 25.4 & 32.4 & 19.5 & 15.2 & 7.4 \\
\hline $15-18$ & 16.1 & 29.2 & 41.3 & 22.3 & 33.8 & 33.1 & 14.7 & 24.1 & 11.1 & 12.1 & 26.0 & 30.4 & 25.4 & 12.4 & 6.0 \\
\hline \multicolumn{16}{|l|}{ Gender } \\
\hline Female & 47.2 & 53.2 & 48.1 & 49.4 & 49.7 & 49.4 & 45 & 49.9 & 44.7 & 46.6 & 48.6 & 49.2 & 50.8 & 44.8 & 45.6 \\
\hline Male & 52.8 & 46.6 & 51.9 & 50.6 & 50.3 & 50.6 & 55 & 50.1 & 55.3 & 53.4 & 51.4 & 50.8 & 49.2 & 55.2 & 54.4 \\
\hline \multicolumn{16}{|l|}{ Comorbidities** } \\
\hline Autistic disorder & 0.9 & - & - & 1.4 & 1.3 & - & 2.3 & 3.5 & - & - & - & - & - & - & - \\
\hline Neonatal disorder & 2.3 & - & - & 1.4 & 0.8 & - & 5.2 & 3.8 & - & - & - & - & - & - & - \\
\hline $\begin{array}{l}\text { Neurodevelopmental } \\
\text { disorder }\end{array}$ & 7.4 & 1.0 & 7.4 & 8.8 & 8.2 & 2.4 & 16.7 & 20.6 & - & - & - & - & - & - & - \\
\hline Asthma & 10.1 & 18.7 & 16.4 & 33.6 & 21.1 & 35.1 & 38.8 & 30.3 & - & - & - & - & - & - & - \\
\hline Obesity & 9.5 & 1.9 & - & 11.7 & 19.6 & - & 13.1 & 20.6 & - & - & - & - & - & - & - \\
\hline Heart disease & 1.9 & 1.2 & - & 13.1 & 7.1 & 3.6 & 37.0 & 18.3 & - & - & - & - & - & - & - \\
\hline $\begin{array}{l}\text { Malignant neoplasm } \\
\text { excluding non- } \\
\text { melanoma skin } \\
\text { cancer }\end{array}$ & 0.3 & - & - & 3.9 & 4.0 & - & 13.2 & 12.5 & - & - & - & - & - & - & - \\
\hline Hypertension & 0.3 & - & - & 8.0 & 2.0 & - & 23.8 & 8.3 & - & - & - & - & - & - & - \\
\hline $\begin{array}{l}\text { Type } 1 \text { diabetes } \\
\text { mellitus }\end{array}$ & 0.2 & - & - & 0.5 & 0.3 & - & 1.6 & $<1.3$ & - & - & - & - & - & - & - \\
\hline
\end{tabular}


medRxiv preprint doi: https://doi.org/10.1101/2020.10.29.20222083; this version posted October 30, 2020. The copyright holder for this preprint (which was not certified by peer review) is the author/funder, who has granted medRxiv a license to display the preprint in perpetuity.

It is made available under a CC-BY 4.0 International license .

\begin{tabular}{|c|c|c|c|c|c|c|c|c|c|c|c|c|c|c|c|}
\hline $\begin{array}{l}\text { Attention deficit } \\
\text { hyperactivity disorder }\end{array}$ & 2.2 & - & - & 4.4 & 5.4 & - & 4.0 & 10.3 & - & - & - & - & - & - & - \\
\hline $\begin{array}{l}\text { Chromosomal } \\
\text { disorder }\end{array}$ & 0.4 & - & - & 1.3 & 0.8 & - & 5.8 & 3.5 & - & - & - & - & - & - & - \\
\hline $\begin{array}{l}\text { Congenital } \\
\text { malformation }\end{array}$ & 10.8 & - & - & 7.9 & 4.7 & 4.4 & 22.7 & 13.5 & - & - & - & - & - & - & - \\
\hline $\begin{array}{l}\text { Congenital heart } \\
\text { disease }\end{array}$ & 0.2 & - & - & 1.2 & 0.6 & - & 5.1 & 3.8 & - & - & - & - & - & - & - \\
\hline Prematurity of infant & 1.0 & - & - & 1.1 & 0.8 & - & 4.1 & 2.0 & - & & - & - & - & - & - \\
\hline
\end{tabular}

\section{Symptoms at index date}

\begin{tabular}{|c|c|c|c|c|c|c|c|c|c|c|c|c|c|c|c|}
\hline Fever & 4.8 & 10.1 & 7.9 & 13.3 & 8.1 & 10.0 & 11.3 & 17.8 & 26.4 & 26.1 & - & 6.2 & 17.8 & 28.1 & 17.7 \\
\hline Cough & 4.7 & 8.2 & 8.5 & 11.5 & 6.3 & 5.6 & 6.1 & 6.3 & 8.2 & 14.5 & 4.6 & 6.3 & 9.7 & 2.9 & 2.8 \\
\hline Dyspnea & 0.3 & - & - & 4.1 & 1.4 & 9.6 & 10.6 & 6.8 & 4.7 & 7.7 & - & 0.7 & 8.6 & 10.0 & 10.9 \\
\hline Malaise or fatigue & - & 1.9 & - & 1.1 & 1.0 & - & 1.0 & 1.5 & - & 1.2 & - & 1.0 & - & - & 1.0 \\
\hline Myalgia & - & - & - & 0.4 & 0.6 & - & 0.3 & - & - & 0.8 & - & 0.2 & - & - & - \\
\hline $\begin{array}{l}\text { Anosmia OR } \\
\text { Hyposmia OR } \\
\text { Dysgeusia }\end{array}$ & - & - & - & 0.5 & 0.9 & - & - & - & - & 0.5 & - & 0.5 & - & - & - \\
\hline $\begin{array}{l}\text { Gastrointestinal tract } \\
\text { symptoms }\end{array}$ & 12.5 & 4.3 & - & 4.9 & 3.4 & 8.0 & 11.6 & 15 & 8.2 & 8.9 & - & 0.5 & 10.3 & 9.0 & 11.6 \\
\hline Diarrhea & 4.0 & - & - & 1.5 & 1.4 & - & 1.9 & 5.0 & 1.9 & 3.1 & - & 0.3 & - & - & 3.1 \\
\hline Vomiting & 1.8 & 1.9 & - & 2.8 & 1.6 & 2.4 & 7.9 & 7.5 & 4.5 & 4.3 & - & 0.2 & 7.0 & 5.7 & 4.2 \\
\hline Nausea & 1.4 & 1.9 & - & 1.4 & 1.1 & 2.0 & 3.6 & 4.5 & - & 1.7 & - & 0.1 & - & - & 0.9 \\
\hline Bronchiolitis & 0.5 & - & - & 3.1 & 0.5 & - & 11.9 & 5.5 & 8.9 & - & - & 0.1 & 9.7 & 11.4 & - \\
\hline \multicolumn{16}{|c|}{ 30-day outcomes following hospitalization } \\
\hline Sepsis & - & - & - & - & 0.4 & - & 6.6 & 6.0 & - & - & - & - & - & 3.3 & 9.4 \\
\hline $\begin{array}{l}\text { Acute respiratory } \\
\text { distress synd rome } \\
\text { (ARDS) }\end{array}$ & - & - & - & - & 0.7 & - & 16.2 & 10.3 & - & - & - & - & - & 8.1 & 22.7 \\
\hline Cardiac arrhythmia & - & - & - & - & 0.3 & - & 5.6 & 4.0 & - & - & - & - & - & 9.0 & 6.1 \\
\hline Bleeding & - & - & - & - & - & - & 2.3 & 2.3 & - & - & - & - & - & - & 3.2 \\
\hline \multicolumn{16}{|l|}{ 30-day outcomes } \\
\hline Death & - & - & - & - & - & - & - & - & - & 0.2 & - & - & - & - & - \\
\hline
\end{tabular}


medRxiv preprint doi: https://doi.org/10.1101/2020.10.29.20222083; this version posted October 30, 2020. The copyright holder for this preprint (which was not certified by peer review) is the author/funder, who has granted medRxiv a license to display the preprint in perpetuity.

\section{It is made available under a CC-BY 4.0 International license.}

\begin{tabular}{|c|c|c|c|c|c|c|c|c|c|c|c|c|c|}
\hline $\begin{array}{l}\text { Hospitalization } \\
\text { episodes }\end{array}$ & 1.4 & - & 13.2 & 7.1 & - & - & - & 33.2 & 36.1 & 0.3 & 30.8 & - & - \\
\hline Pneumonia & 3.1 & - & 6.5 & 0.9 & 6.8 & 20.3 & 11.8 & 4.5 & - & 0.1 & - & 7.6 & - \\
\hline $\begin{array}{l}\text { Multi-system } \\
\text { inflammatory } \\
\text { syndrome in children } \\
\text { (MIS-C) }\end{array}$ & & - & 0.3 & 0.3 & - & 1.4 & 3.5 & 3.1 & 0.4 & 0.0 & - & 7.6 & 0.9 \\
\hline
\end{tabular}

*Proportions presented among diagnosed or hospitalized patients by database (column percentage); - data not available or below the minimum cell count required ( 5 individuals); children aged $<1$ year were excluded when at least 1 year of prior observation time was required.

**Comorbidities are reported only in those databases with at least 1 year of prior observation time. Abbreviations: Colorado University Anschuz Medical Campus Health Data Compass (CU-AMC HDC), Columbia University Irving Medical Center (CUIMC), Data Analyzer (DA), Health Insurance Review \& Assessment Service (HIRA), Information System for Research in Primary Care (SIDIAP), STAnford medicine Research data Repository (STARR-OMOP), Longitudinal Patient Data (LPD).

Figure 2. Prevalence of previous comorbidities among children/adolescents ( $<18$ years of age) diagnosed ( $X$ axis) compared to hospitalized ( $Y$ axis) with COVID-19. SMD = Standardized Mean Differences in prevalence between $X$ and $Y$.

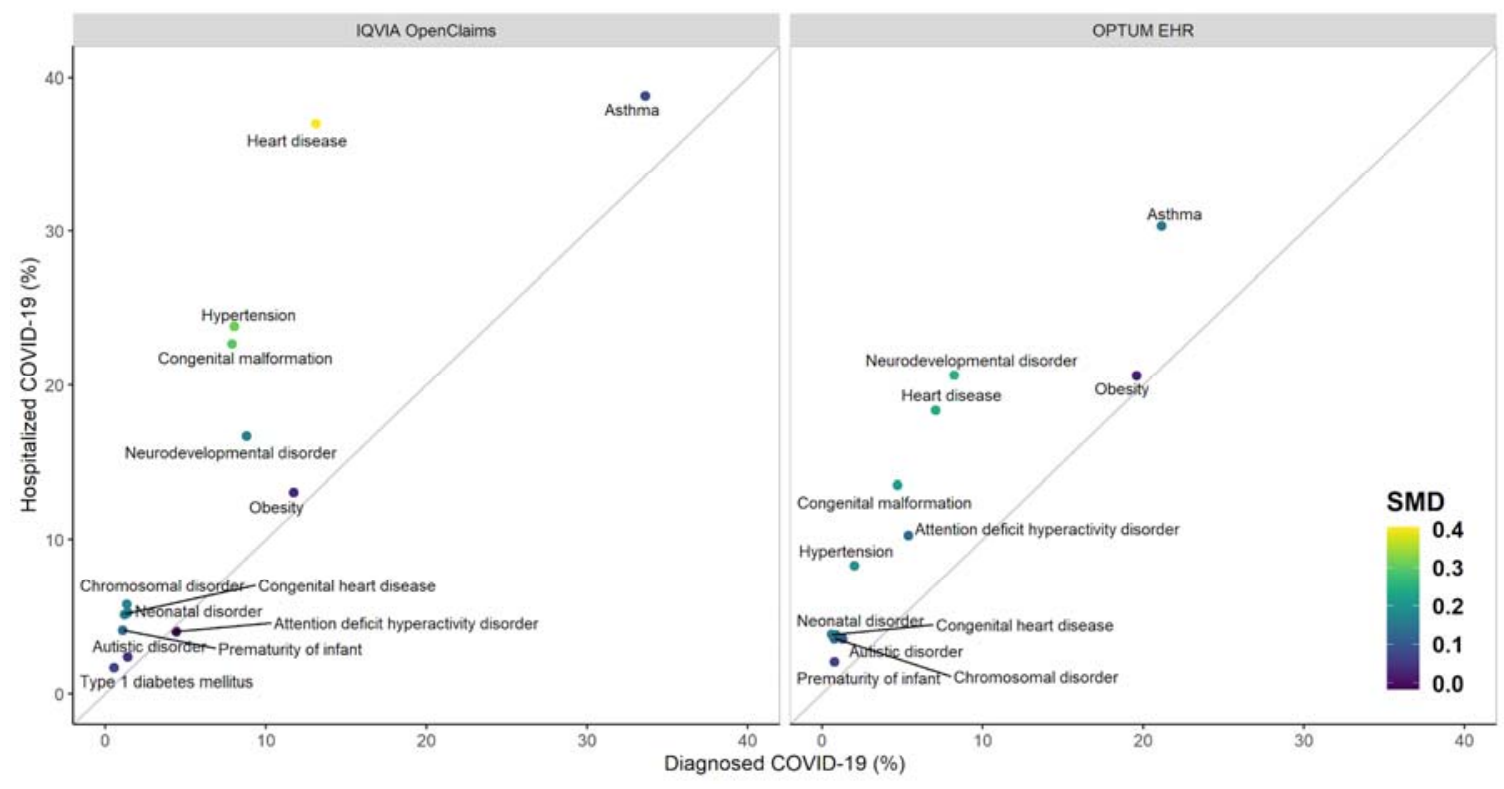


medRxiv preprint doi: https://doi.org/10.1101/2020.10.29.20222083; this version posted October 30, 2020. The copyright holder for this preprint (which was not certified by peer review) is the author/funder, who has granted medRxiv a license to display the preprint in perpetuity.

It is made available under a CC-BY 4.0 International license.

Figure 3. Symptoms recorded at index date among children/adolescents ( $<18$ years of age)

A. Diagnosed compared to hospitalized with COVID-19

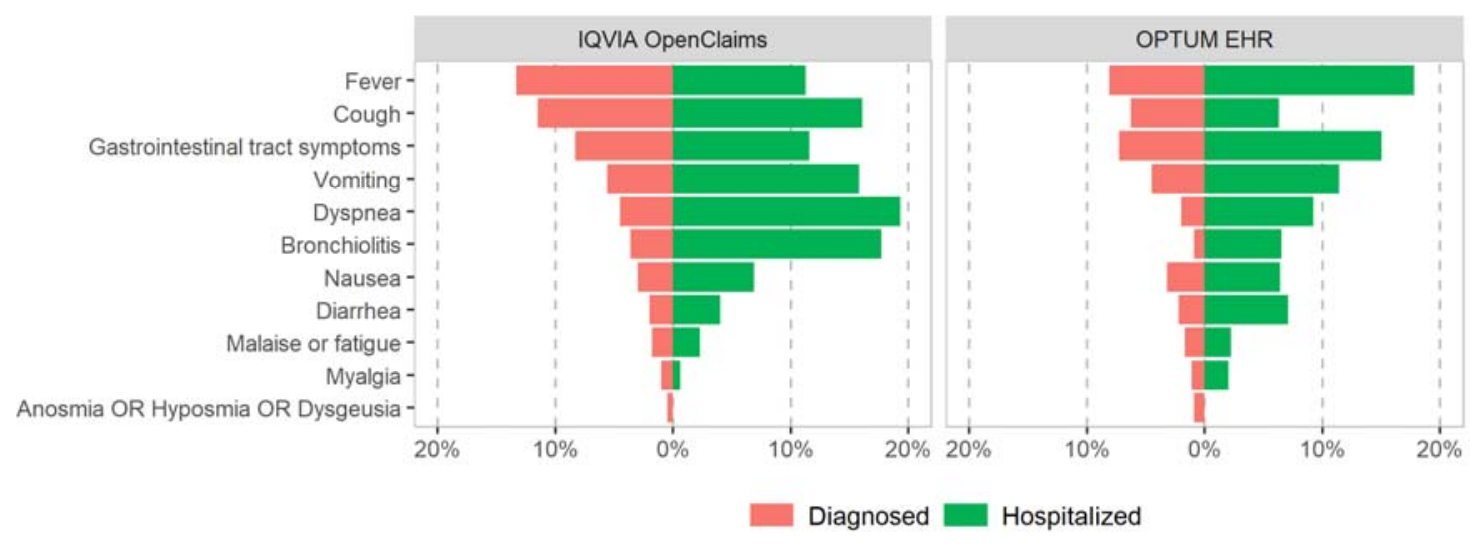

B. Diagnosed with COVID-19 compared to diagnosed with seasonal influenza (2017-2018)

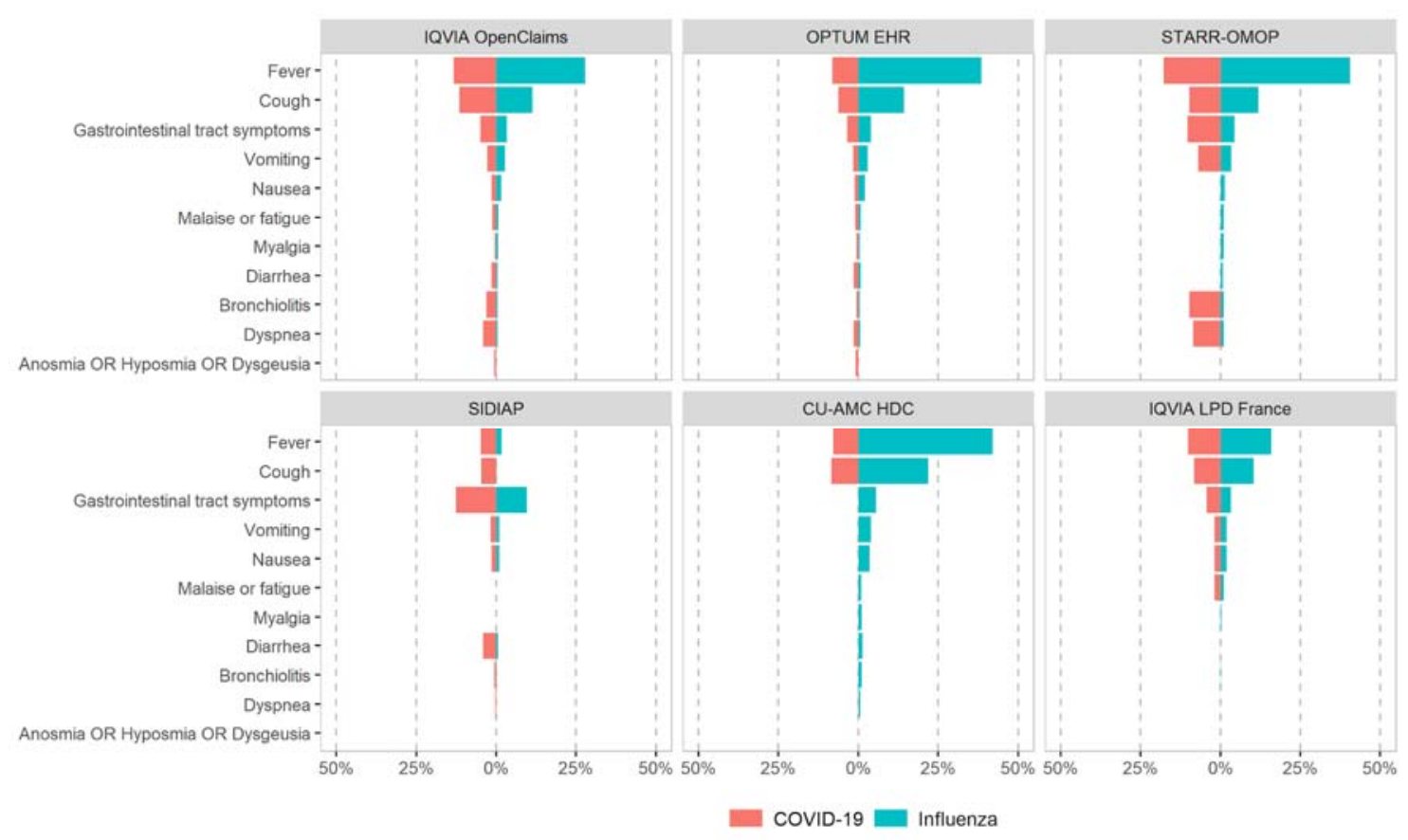


medRxiv preprint doi: https://doi.org/10.1101/2020.10.29.20222083; this version posted October 30, 2020. The copyright holder for this preprint (which was not certified by peer review) is the author/funder, who has granted medRxiv a license to display the preprint in perpetuity.

It is made available under a CC-BY 4.0 International license.

Figure 4. 30-day in-hospital use of treatments among children/adolescents ( $<18$ years of age) with COVID-19

A. Repurposed drugs

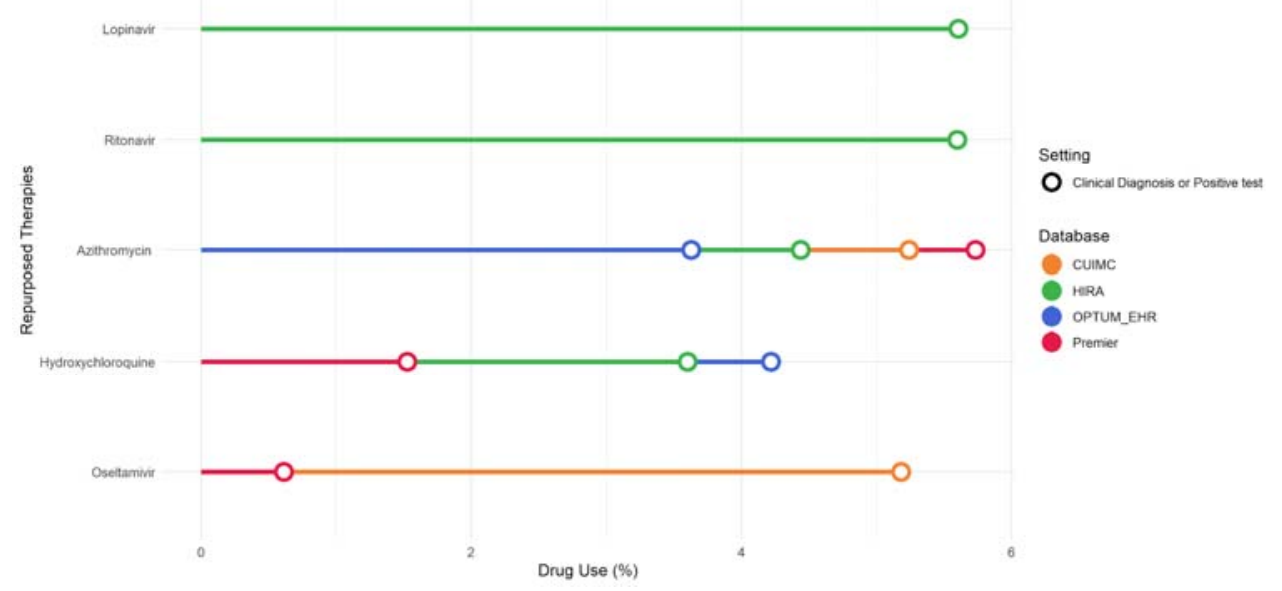

B. Adjunctive therapies

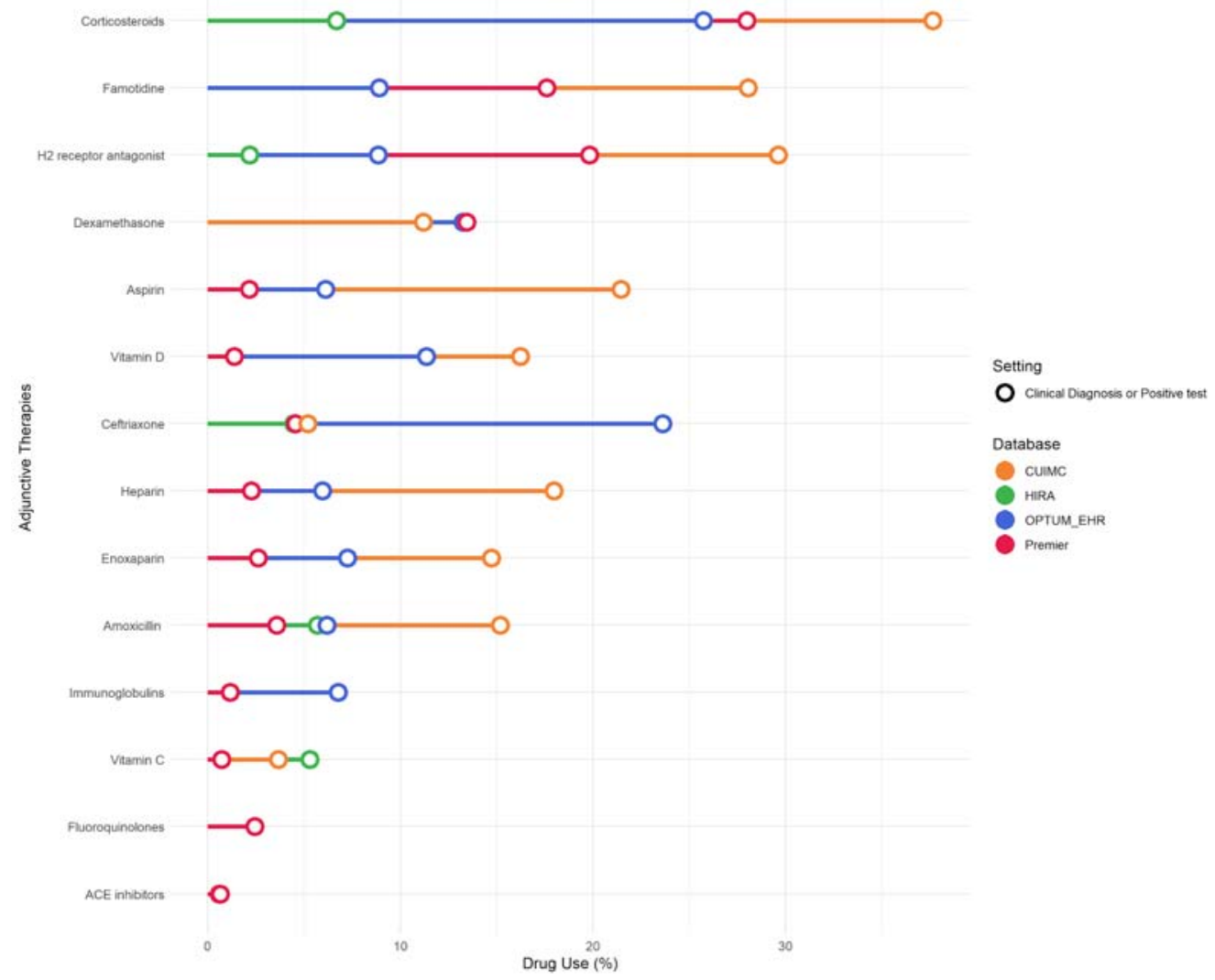


medRxiv preprint doi: https://doi.org/10.1101/2020.10.29.20222083; this version posted October 30, 2020. The copyright holder for this preprint (which was not certified by peer review) is the author/funder, who has granted medRxiv a license to display the preprint in perpetuity.

It is made available under a CC-BY 4.0 International license.

Figure 5. Main 30-day outcomes among children/adolescents (<18 years of age)

A. Diagnosed compared to hospitalized with COVID-19

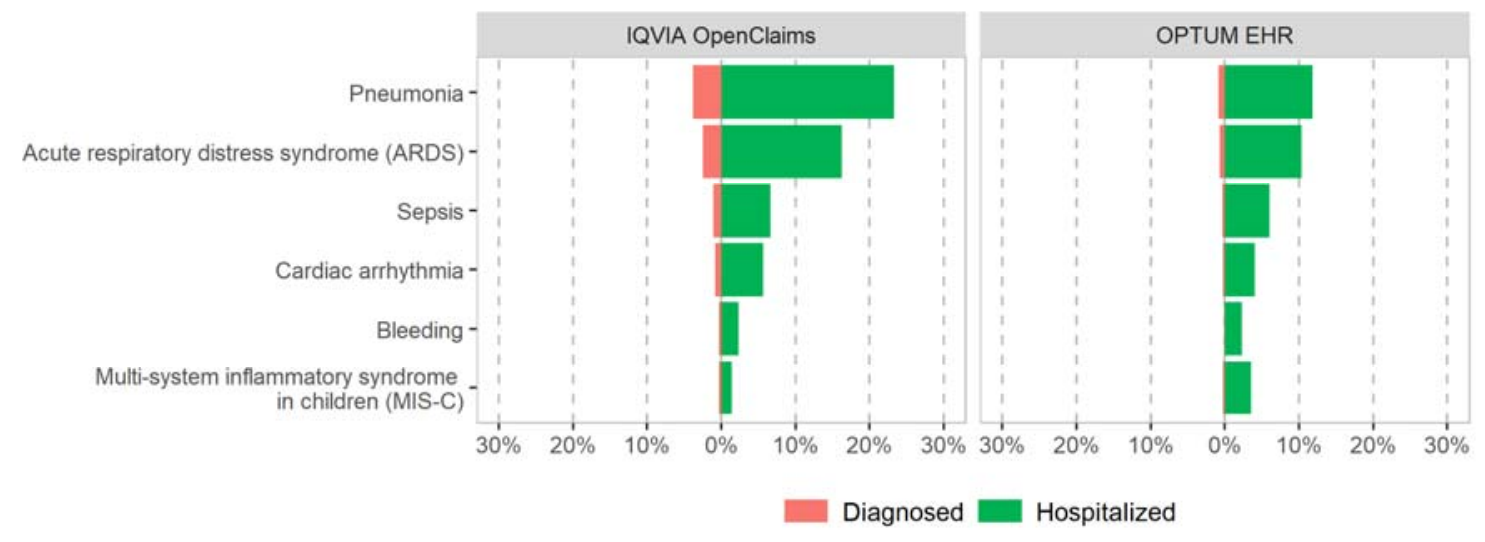

B. Diagnosed with COVID-19 compared to diagnosed with seasonal influenza (2017-2018)

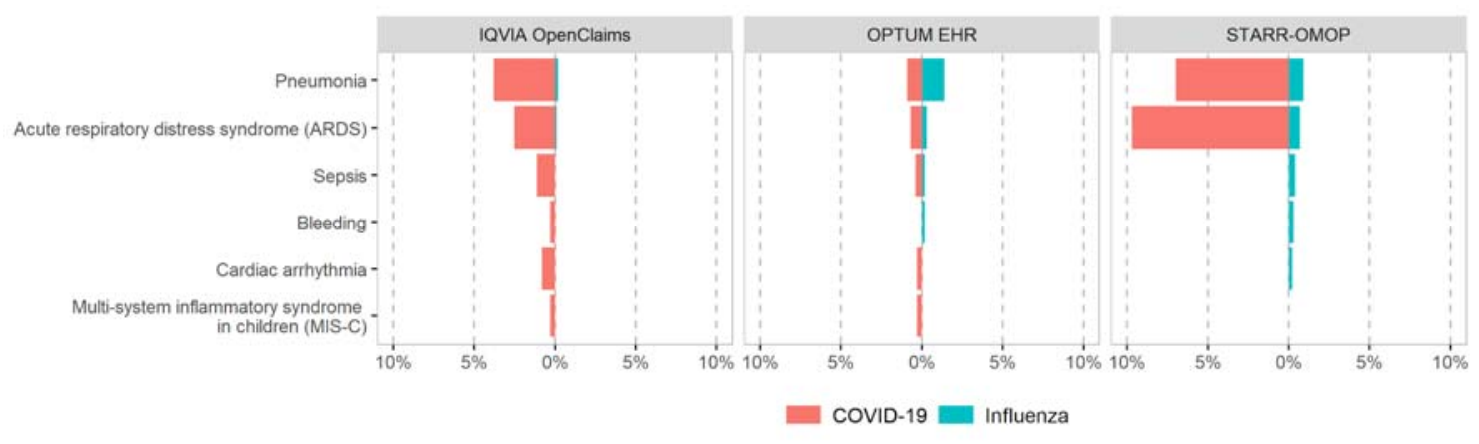


Supplementary Table 1. Overview of data sources contributing results.

\begin{tabular}{|c|c|c|c|}
\hline Database Name & Country & Description & Contributed By \\
\hline $\begin{array}{l}\text { Columbia } \\
\text { University Irving } \\
\text { Medical Center } \\
\text { (CUIMC) }\end{array}$ & United States & $\begin{array}{l}\text { The clinical data warehouse of } \\
\text { NewYork-Presbyterian } \\
\text { Hospital/Columbia University Irving } \\
\text { Medical Center, New York, NY, } \\
\text { based on its current and previous } \\
\text { electronic health record systems, } \\
\text { with data spanning over } 30 \text { years } \\
\text { and including over } 6 \text { million } \\
\text { patients }\end{array}$ & $\begin{array}{l}\text { Department of } \\
\text { Biomedical } \\
\text { Informatics, } \\
\text { Columbia } \\
\text { University Irving } \\
\text { Medical Center, } \\
\text { New York, NY } \\
10032 \text {, USA }\end{array}$ \\
\hline $\begin{array}{l}\text { IQVIA Disease } \\
\text { Analyser (DA) } \\
\text { Germany }\end{array}$ & Germany & $\begin{array}{l}\text { IQVIA DA Germany is collected } \\
\text { from extracts of patient } \\
\text { management software used by GPs } \\
\text { and specialists practicing in } \\
\text { ambulatory care settings. Data } \\
\text { coverage includes more than } 34 \mathrm{M} \\
\text { distinct person records out of at } \\
\text { total population of } 80 \mathrm{M}(42.5 \%) \text { in } \\
\text { the country and collected from } \\
2,734 \text { providers. Dates of service } \\
\text { include from } 1992 \text { through March } \\
2020 \text {. }\end{array}$ & $\begin{array}{l}\text { Real World } \\
\text { Solutions, IQVIA } \\
\text { Inc, Cambridge, } \\
\text { MA, USA }\end{array}$ \\
\hline HealthVerity & United States & $\begin{array}{l}\text { This HealthVerity derived data set } \\
\text { contains de-identified patient } \\
\text { information with an antibody } \\
\text { and/or diagnostic test for COVID- } \\
19 \text { linked to all available Medical } \\
\text { Claims and Pharmacy Data from } \\
\text { select private data providers } \\
\text { participating in the HealthVerity } \\
\text { marketplace. }\end{array}$ & $\begin{array}{l}\text { Janssen } \\
\text { Research \& } \\
\text { Development, } \\
\text { Titusville, NJ, } \\
\text { USA }\end{array}$ \\
\hline $\begin{array}{l}\text { Health Insurance } \\
\text { Review \& } \\
\text { Assessment } \\
\text { Service (HIRA) }\end{array}$ & South Korea & $\begin{array}{l}\text { National claim data from a single } \\
\text { insurance service from South } \\
\text { Korea. It contains the observational } \\
\text { medical records (including both } \\
\text { inpatient and outpatient) of a } \\
\text { patient while they are qualified to } \\
\text { get the national medical insurance. }\end{array}$ & $\begin{array}{l}\text { Health Insurance } \\
\text { Review \& } \\
\text { Assessment } \\
\text { Service, } 60 \\
\text { Hyeoksin-Rho, } \\
\text { Wonju-Si, } \\
\text { Gangwon- } \\
\text { Do(Bangkok- } \\
\text { Dong), 26465, } \\
\text { Korea }\end{array}$ \\
\hline
\end{tabular}


IQVIA Open

Claims

IQVIA

Longitudinal

Patient Data

(LPD) France

OPTUM-EHR

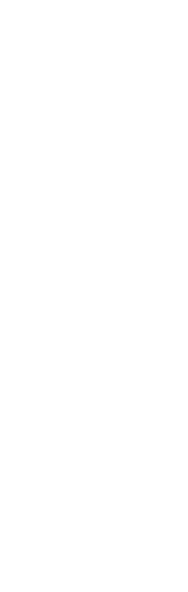

France
A United States database of open,

pre-adjudicated claims from January 2013 to May 2020. Data

are reported at anonymized

patient level collected from office-

based physicians and specialists via office management software and clearinghouse switch sources for the purpose of reimbursement. A subset of medical claims data have adjudicated claims.

LPD France is a computerised network of physicians including GPs who contribute to a centralised database of anonymised patient EMR. Currently, >1200 GPs from 400 practices are contributing to the database covering $7.8 \mathrm{M}$ patients in France. The database covers a time period from 1994 through the present. Observation time is defined by the first and last consultation dates. Drug information is derived from GP prescriptions. Drugs obtained over the counter by the patient outside the prescription system are not reported.

United States
Optum $^{\circledR}$ de-identified COVID-19

Electronic Health Record dataset

represents Optum's Electronic

Health Record data a medical

records database for patients

receiving a COVID-19 diagnosis

record or lab test for SARS-CoV-2.

The medical record data includes

clinical information, inclusive of

prescriptions as prescribed and

administered, lab results, vital

signs, body measurements,

diagnoses, procedures, and information derived from clinical Notes using Natural Language

Processing (NLP).
Real World

Solutions, IQVIA

Inc, Cambridge, MA, USA

Real World

Solutions, IQVIA

Inc, Cambridge,

MA, USA

Janssen

Research \& Development, Titusville, NJ,

USA 


\begin{tabular}{|c|c|c|c|}
\hline $\begin{array}{l}\text { Premier } \\
\text { Healthcare } \\
\text { Database }\end{array}$ & United States & $\begin{array}{l}\text { The Premier Healthcare Database } \\
\text { contains complete clinical coding, } \\
\text { hospital cost, and patient billing } \\
\text { data from approximately } 700 \\
\text { hospitals throughout the United } \\
\text { States representing } 20 \% \text { of } \\
\text { inpatient hospital stays. Premier } \\
\text { collects data from participating } \\
\text { hospitals in its health care alliance. } \\
\text { The Premier health care alliance } \\
\text { was formed for hospitals to share } \\
\text { knowledge, improve patient safety, } \\
\text { and reduce risks. Participation in } \\
\text { the Premier health care alliance is } \\
\text { voluntary. Although the database } \\
\text { excludes federally funded hospitals } \\
\text { (e.g., Veterans Affairs), the } \\
\text { hospitals included are nationally } \\
\text { representative based on bed size, } \\
\text { geographic region, location } \\
\text { (urban/rural) and teaching hospital } \\
\text { status. The database contains a } \\
\text { date-stamped log of all billed items } \\
\text { by cost-accounting department } \\
\text { including medications; laboratory, } \\
\text { diagnostic, and therapeutic } \\
\text { services; and primary and } \\
\text { secondary diagnoses for each } \\
\text { patientâ }{ }^{\text {TM }} \text { s hospitalization. }\end{array}$ & $\begin{array}{l}\text { Janssen } \\
\text { Research \& } \\
\text { Development, } \\
\text { Titusville, NJ, } \\
\text { USA }\end{array}$ \\
\hline $\begin{array}{l}\text { Information } \\
\text { System for } \\
\text { Research in } \\
\text { Primary Care } \\
\text { (SIDIAP) }\end{array}$ & Spain & $\begin{array}{l}\text { The Information System for } \\
\text { Research in Primary Care (SIDIAP; } \\
\text { www.sidiap.org) is a primary care } \\
\text { records database that covers } \\
\text { approximately } 7 \text { million people, } \\
\text { equivalent to an } 80 \% \text { of the } \\
\text { population of Catalonia, North-East } \\
\text { Spain. Healthcare is universal and } \\
\text { tax-payer funded in the region, and } \\
\text { primary care physicians are } \\
\text { gatekeepers for all care and } \\
\text { responsible for repeat } \\
\text { prescriptions. }\end{array}$ & $\begin{array}{l}\text { Fundacio Institut } \\
\text { Universitari per } \\
\text { a la recerca a } \\
\text { I'Atencio } \\
\text { Primaria de Salut } \\
\text { Jordi Gol i Gurina } \\
\text { (IDIAPJGol), } \\
\text { Barcelona, Spain }\end{array}$ \\
\hline
\end{tabular}




\begin{tabular}{|c|c|c|c|}
\hline $\begin{array}{l}\text { STAnford } \\
\text { medicine } \\
\text { Research data } \\
\text { Repository } \\
\text { (STARR-OMOP) }\end{array}$ & United States & $\begin{array}{l}\text { STAnford medicine Research data } \\
\text { Repository, a clinical data } \\
\text { warehouse containing live Epic } \\
\text { data from Stanford Health Care, } \\
\text { the Stanford Children's Hospital, } \\
\text { the University Healthcare Alliance } \\
\text { and Packard Children's Health } \\
\text { Alliance clinics and other auxiliary } \\
\text { data from Hospital applications } \\
\text { such as radiology PACS. STARR } \\
\text { platform is developed and } \\
\text { operated by Stanford Medicine } \\
\text { Research IT team and is made } \\
\text { possible by Stanford School of } \\
\text { Medicine Research Office. }\end{array}$ & $\begin{array}{l}\text { Department of } \\
\text { Medicine, School } \\
\text { of Medicine, } \\
\text { Stanford } \\
\text { University, } \\
\text { Redwood City, } \\
\text { CA USA }\end{array}$ \\
\hline $\begin{array}{l}\text { U of Colorado } \\
\text { Anschuz Medical } \\
\text { Campus Health } \\
\text { Data Compass } \\
\text { (CU-AMC-HDC) }\end{array}$ & United States & $\begin{array}{l}\text { Health Data Compass (HDC) is a } \\
\text { multi-institutional data warehouse. } \\
\text { HDC contains inpatient and } \\
\text { outpatient electronic medical data } \\
\text { including patient, encounter, } \\
\text { diagnosis, procedures, } \\
\text { medications, laboratory results } \\
\text { from two electronic medical record } \\
\text { systems (UCHealth and Children's } \\
\text { Hospital of Colorado), state-level } \\
\text { all-payers claims data, and the } \\
\text { Colorado death registry. } \\
\text { Acknowledgement statement: } \\
\text { Supported by the Health Data } \\
\text { Compass Data Warehouse project } \\
\text { (healthdatacompass. org). }\end{array}$ & $\begin{array}{l}\text { Data Science to } \\
\text { Patient Value } \\
\text { Program, } \\
\text { Department of } \\
\text { Medicine, } \\
\text { University of } \\
\text { Colorado } \\
\text { Anschutz } \\
\text { Medical Campus, } \\
\text { Aurora, } \\
\text { Colorado, USA }\end{array}$ \\
\hline
\end{tabular}


medRxiv preprint doi: https://doi.org/10.1101/2020.10.29.20222083; this version posted October 30, 2020. The copyright holder for this preprint (which was not certified by peer review) is the author/funder, who has granted medRxiv a license to display the preprint in perpetuity.

It is made available under a CC-BY 4.0 International license.

Supplementary Table 2. Cohort definitions and codes.

\begin{tabular}{|c|c|}
\hline Name & Atlas Link \\
\hline \multicolumn{2}{|l|}{ COVID-19 } \\
\hline $\begin{array}{l}\text { Persons tested with a COVID-19 diagnosis record or a SARS- } \\
\text { CoV- } 2 \text { positive test with at least } 365 \mathrm{~d} \text { prior observation }\end{array}$ & https://atlas.ohdsi.org/\#/cohortdefinition/202 \\
\hline $\begin{array}{l}\text { Persons hospitalized with a COVID- } 19 \text { diagnosis record or a } \\
\text { SARS-CoV- } 2 \text { positive test with at least } 365 \mathrm{~d} \text { prior } \\
\text { observation }\end{array}$ & https://atlas.ohdsi.org/\#/cohortdefinition/197 \\
\hline $\begin{array}{l}\text { Persons tested with a COVID- } 19 \text { diagnosis record or a SARS- } \\
\text { CoV- } 2 \text { positive test with no required prior observation }\end{array}$ & http://atlas-covid19.ohdsi.org/\#/cohortdefinition/970 \\
\hline $\begin{array}{l}\text { Persons hospitalized with a COVID- } 19 \text { diagnosis record or a } \\
\text { SARS-CoV- } 2 \text { positive test with no required prior } \\
\text { observation }\end{array}$ & http://atlas-covid19.ohdsi.org/\#/cohortdefinition/974 \\
\hline \multicolumn{2}{|l|}{$\underline{\text { Influenza }}$} \\
\hline $\begin{array}{l}\text { Persons with Influenza diagnosis or positive test 2017-2018 } \\
\text { with at least } 365 \text { d prior observation }\end{array}$ & https://atlas.ohdsi.org/\#/cohortdefinition/211 \\
\hline $\begin{array}{l}\text { Persons hospitalized with influenza diagnosis or positive } \\
\text { test } 2017-2018 \text { with at least } 365 \text { d prior observation }\end{array}$ & $\underline{\text { https://atlas.ohdsi.org/\#/cohortdefinition/212 }}$ \\
\hline $\begin{array}{l}\text { Persons with Influenza diagnosis or positive test 2017-2018 } \\
\text { with no required prior observation }\end{array}$ & http://atlas-covid19.ohdsi.org/\#/cohortdefinition/958 \\
\hline $\begin{array}{l}\text { Persons hospitalized with influenza diagnosis or positive } \\
\text { test } 2017-2018 \text { with no required prior observation }\end{array}$ & http://atlas-covid19.ohdsi.org/\#/cohortdefinition/961 \\
\hline \multicolumn{2}{|l|}{ Comorbidities? } \\
\hline Asthma回回 & https://atlas.ohdsi.org/\#/cohortdefinition/218 ? \\
\hline Heart disease? & https://atlas.ohdsi.org/\#/cohortdefinition/231 ? \\
\hline Hypertension国 & https://atlas.ohdsi.org/\#/cohortdefinition/227 ? \\
\hline Malignant neoplasm excluding non-melanoma skin cancer?] & https://atlas.ohdsi.org/\#/cohortdefinition/222] \\
\hline Obesity? & https://atlas.ohdsi.org/\#/cohortdefinition/224 ? \\
\hline Autistic disorder & $\underline{\text { https://atlas.ohdsi.org/\#/concept/439780 }}$ \\
\hline
\end{tabular}


medRxiv preprint doi: https://doi.org/10.1101/2020.10.29.20222083; this version posted October 30, 2020. The copyright holder for this preprint (which was not certified by peer review) is the author/funder, who has granted medRxiv a license to display the preprint in perpetuity.

It is made available under a CC-BY 4.0 International license.

\begin{tabular}{|c|c|}
\hline Neonatal disorder & https://atlas.ohdsi.org/\#/concept/4042220 \\
\hline Neurodevelopmental disorder & https://atlas.ohdsi.org/\#/concept/45771096 \\
\hline Type 1 diabetes mellitus & https://atlas.ohdsi.org/\#/concept/201254 \\
\hline Attention deficit hyperactivity disorder & https://atlas.ohdsi.org/\#/concept/438409 \\
\hline Chromosomal disorder & https://atlas.ohdsi.org/\#/concept/4257441 \\
\hline Congenital malformation & https://atlas.ohdsi.org/\#/concept/4079975 \\
\hline Congenital heart disease & https://atlas.ohdsi.org/\#/concept/312723 \\
\hline Prematurity of infant & https://atlas.ohdsi.org/\#/concept/36675035 \\
\hline Outcomes & \\
\hline During hospitalization & \\
\hline Sepsis during hospitalization & https://atlas.ohdsi.org/\#/cohortdefinition/277 \\
\hline $\begin{array}{l}\text { Acute Respiratory Distress syndrome (ARDS) during } \\
\text { hospitalization }\end{array}$ & https://atlas.ohdsi.org/\#/cohortdefinition/278 \\
\hline Cardiac arrhythmia & https://atlas.ohdsi.org/\#/cohortdefinition/248 \\
\hline Bleeding & https://atlas.ohdsi.org/\#/cohortdefinition/238 \\
\hline 30-day outcomes & \\
\hline Death & http://atlas-covid19.ohdsi.org/\#/cohortdefinition/166 \\
\hline Hospitalization episodes & http://atlas-covid19.ohdsi.org/\#/cohortdefinition/917 \\
\hline Pneumonia & http://atlas-covid19.ohdsi.org/\#/cohortdefinition/938 \\
\hline Multi-system inflammatory syndrome in children (MIS-C) & http://atlas-covid19.ohdsi.org/\#/cohortdefinition/940 \\
\hline
\end{tabular}


medRxiv preprint doi: https://doi.org/10.1101/2020.10.29.20222083; this version posted October 30, 2020. The copyright holder for this preprint (which was not certified by peer review) is the author/funder, who has granted medRxiv a license to display the preprint in perpetuity.

It is made available under a CC-BY 4.0 International license.

Supplementary Table 3. Demographics, comorbidities, symptoms and outcomes among diagnosed with seasonal influenza (2017-2018) among children/adolescents aged below 18 years*

\begin{tabular}{|c|c|c|c|c|c|c|c|c|c|}
\hline & \multicolumn{5}{|c|}{ At least 1 year of prior observation } & \multicolumn{4}{|c|}{ No prior observation time } \\
\hline & $\begin{array}{l}\text { SIDIAP } \\
\text { (Spain) }\end{array}$ & $\begin{array}{l}\text { IQVIA } \\
\text { LPD } \\
\text { (France) }\end{array}$ & $\begin{array}{l}\text { CU-AMC } \\
\text { HDC } \\
\text { (US) }\end{array}$ & $\begin{array}{l}\text { IQVIA } \\
\text { OpenClai } \\
\text { ms (US) }\end{array}$ & $\begin{array}{l}\text { OPTUM } \\
\text { EHR (US) }\end{array}$ & $\begin{array}{l}\text { CUIMC } \\
\text { (US) }\end{array}$ & $\begin{array}{l}\text { IQVIA DA } \\
\text { (German } \\
\text { y) }\end{array}$ & $\begin{array}{l}\text { HealthVe } \\
\text { rity (US) }\end{array}$ & $\begin{array}{l}\text { STARR- } \\
\text { OMOP } \\
\text { (US) }\end{array}$ \\
\hline & $n=26929$ & $n=22425$ & $n=3339$ & $\begin{array}{l}n=187348 \\
0\end{array}$ & $n=3665$ & $n=2112$ & $n=19863$ & $n=502$ & $n=2831$ \\
\hline \multicolumn{10}{|l|}{ Age (years) } \\
\hline $00-04$ & 22.0 & 20.8 & 23.7 & 24.4 & 24.1 & 40.2 & 29.3 & 21.7 & 25.3 \\
\hline $05-09$ & 36.7 & 35.3 & 35.6 & 37.5 & 31.3 & 36.2 & 35.7 & 29.7 & 34.7 \\
\hline $10-14$ & 29.2 & 27.0 & 27.0 & 26.3 & 24.9 & 17.2 & 23.3 & 23.7 & 27.8 \\
\hline $15-19$ & 12.0 & 17.0 & 13.6 & 11.8 & 19.7 & 6.5 & 11.7 & 24.9 & 12.2 \\
\hline \multicolumn{10}{|l|}{ Gender } \\
\hline Female & 47.5 & 47.8 & 49.6 & 48.5 & 50.9 & 48.2 & 47.4 & 50.6 & 46.2 \\
\hline Male & 52.5 & 51.9 & 50.4 & 51.5 & 49.1 & 51.8 & 52.6 & 49.4 & 53.8 \\
\hline \multicolumn{10}{|l|}{ Comorbidities** } \\
\hline Autistic disorder & 0.5 & - & 0.9 & 1.0 & 1.4 & - & - & - & - \\
\hline Neonatal disorder & 2.4 & - & 0.9 & 0.3 & 0.9 & - & - & - & - \\
\hline $\begin{array}{l}\text { Neurodevelopmenta } \\
\text { I disorder }\end{array}$ & 6.7 & 0.6 & 3.5 & 6.4 & 10.2 & - & - & - & - \\
\hline Asthma & 8.6 & 16.4 & 15.9 & 27.5 & 29.7 & - & - & - & - \\
\hline Obesity & 8.3 & 1.5 & 3.4 & 4.2 & 13.9 & - & - & - & - \\
\hline Heart disease & 1.8 & 0.4 & 2.3 & 4.5 & 7.2 & - & - & - & - \\
\hline $\begin{array}{l}\text { Malignant neoplasm } \\
\text { excluding non- } \\
\text { melanoma skin } \\
\text { cancer }\end{array}$ & 0.1 & 0.1 & - & 0.5 & 3.5 & - & - & - & - \\
\hline Hypertension & 0.1 & 0.1 & 0.4 & 1.1 & 1.2 & - & - & - & - \\
\hline $\begin{array}{l}\text { Type } 1 \text { diabetes } \\
\text { mellitus }\end{array}$ & 0.1 & 0.0 & - & 0.2 & 0.4 & - & - & - & - \\
\hline $\begin{array}{l}\text { Attention deficit } \\
\text { hyperactivity } \\
\text { disorder }\end{array}$ & 2.4 & 0.0 & 1.7 & 4.5 & 6.7 & - & - & - & - \\
\hline
\end{tabular}




\begin{tabular}{|l|l|l|l|l|l|l|l|l|}
\hline $\begin{array}{l}\text { Chromosomal } \\
\text { disorder }\end{array}$ & 0.1 & - & 0.4 & 0.3 & 0.8 & - & - & - \\
\hline $\begin{array}{l}\text { Congenital } \\
\text { malformation }\end{array}$ & 11.2 & 0.4 & 2.5 & 2.7 & 4.7 & - & - & - \\
\hline $\begin{array}{l}\text { Congenital heart } \\
\text { disease }\end{array}$ & 0.2 & - & 0.3 & 0.3 & 0.6 & - & - & - \\
\hline $\begin{array}{l}\text { Prematurity of } \\
\text { infant }\end{array}$ & 0.6 & - & 0.4 & 0.2 & 0.6 & - & - & - \\
\hline
\end{tabular}

Symptoms at index date

\begin{tabular}{|l|l|l|l|l|l|l|l|l|l|}
\hline Fever & 1.7 & 15.9 & 42.1 & 27.9 & 38.6 & 51.8 & 9.3 & 31.3 & 40.6 \\
\hline Cough & 0.2 & 10.4 & 21.9 & 11.4 & 14.4 & 16 & 4.1 & 16.9 & 11.8 \\
\hline Dyspnea & 0.0 & 0.0 & 0.6 & 0.4 & 0.6 & 2.2 & 0.9 & - & 1.1 \\
\hline Malaise or fatigue & 0.0 & 1.0 & 0.9 & 0.7 & 0.7 & 0.5 & 0.4 & - & 1.1 \\
\hline Myalgia & 0.0 & 0.3 & 1.0 & 0.6 & 0.5 & 0.5 & 0.1 & - & 1.0 \\
\hline $\begin{array}{l}\text { Anosmia OR } \\
\text { Hyposmia OR }\end{array}$ & & & & & & & & & \\
\hline Dysgeusia & - & - & - & 0.0 & - & - & - & - & - \\
\hline $\begin{array}{l}\text { Gastrointestinal } \\
\text { tract symptoms }\end{array}$ & 9.6 & 3.2 & 5.6 & 3.4 & 3.9 & 6.1 & 2.3 & 5.4 & 4.5 \\
\hline Diarrhea & 0.6 & 0.0 & 1.3 & 0.5 & 0.8 & 0.9 & - & - & 0.8 \\
\hline Vomiting & 1.1 & 2.0 & 3.9 & 2.8 & 2.9 & 4.9 & 1.9 & 4.4 & 3.4 \\
\hline Nausea & 1.1 & 2.0 & 3.5 & 1.6 & 2.1 & 0.6 & 2.0 & 3.2 & 1.4 \\
\hline Bronchiolitis & 0.2 & 0.2 & 1.0 & 0.5 & 0.4 & 0.8 & 0.0 & - & 1.1 \\
\hline
\end{tabular}

\section{0-day outcomes during hospitalization}

\begin{tabular}{|l|l|l|l|l|l|l|l|l|l}
\hline Sepsis & - & - & - & - & 0.2 & 0.4 & - & - & 0.4 \\
\hline $\begin{array}{l}\text { Acute respiratory } \\
\text { distress syndrome } \\
\text { (ARDS) }\end{array}$ & - & - & - & 0.1 & 0.3 & 0.7 & - & - & 0.7 \\
\hline Cardiac arrhythmia & - & - & - & - & - & 0.7 & - & - & 0.2 \\
\hline Bleeding & - & - & - & - & 0.2 & 0.6 & - & - & 0.3 \\
\hline
\end{tabular}

\section{0-day outcomes}

\begin{tabular}{|l|l|l|l|l|l|l|l|l|l|}
\hline Death & - & - & - & - & - & - & - & - & - \\
\hline $\begin{array}{l}\text { Hospitalization } \\
\text { episodes }\end{array}$ & - & - & 1.6 & 0.9 & 18.7 & 7.4 & - & 1.4 & 3.7 \\
\hline $\begin{array}{l}\text { Pneumonia } \\
\begin{array}{l}\text { Multi-system } \\
\text { inflammatory } \\
\text { syndrome in children } \\
\text { (MIS-C) }\end{array}\end{array}$ & 0.7 & 0.4 & 2.2 & 2.4 & 1.4 & 3.1 & 2.0 & - & 2.4 \\
\hline
\end{tabular}


*Proportions presented among diagnosed or hospitalized patients by database (column percentage); - data not available or below the minimum cell count required ( 5 individuals); children aged $<1$ year were excluded when at least 1 year of prior observation time was required.

**Comorbidities are reported only in those databases with at least 1 year of prior observation time.

Abbreviations: Colorado University Anschuz Medical Campus Health Data Compass (CU-AMC HDC), Columbia University Irving Medical Center (CUIMC), Data Analyzer (DA), Health Insurance Review \& Assessment Service (HIRA), Information System for Research in Primary Care (SIDIAP), STAnford medicine Research data Repository (STARR-OMOP), Longitudinal Patient Data (LPD).

Supplementary Table 4. Characteristics of diagnosed and hospitalized COVID-19 children/adolescents with no prior observation time in those databases with available observation time*

\begin{tabular}{|c|c|c|c|c|c|c|c|c|}
\hline & \multicolumn{5}{|c|}{ Diagnosed } & \multicolumn{3}{|c|}{ Hospitalized } \\
\hline & $\begin{array}{l}\text { SIDIAP } \\
\text { (Spain) }\end{array}$ & $\begin{array}{l}\text { IQVIA } \\
\text { LPD } \\
\text { (France) }\end{array}$ & $\begin{array}{l}\text { CU- } \\
\text { AMC } \\
\text { HDC } \\
\text { (US) }\end{array}$ & $\begin{array}{l}\text { IQVIA } \\
\text { OpenClaims } \\
\text { (US) }\end{array}$ & $\begin{array}{l}\text { OPTUM } \\
\text { EHR } \\
\text { (US) }\end{array}$ & $\begin{array}{l}\text { HIRA } \\
\text { (South } \\
\text { Korea) }\end{array}$ & $\begin{array}{l}\text { IQVIA } \\
\text { OpenClaims } \\
\text { (US) }\end{array}$ & $\begin{array}{l}\text { OPTUM } \\
\text { EHR } \\
\text { (US) }\end{array}$ \\
\hline & $\begin{array}{l}n= \\
5037\end{array}$ & $n=979$ & $\begin{array}{l}n= \\
286\end{array}$ & $n=17618$ & $\begin{array}{l}n= \\
7737\end{array}$ & $n=251$ & $n=3055$ & $n=748$ \\
\hline \multicolumn{9}{|l|}{ Comorbidities } \\
\hline Autistic disorder & 0.7 & - & - & 0.4 & 0.3 & - & 0.9 & 1.9 \\
\hline Neonatal disorder & 1.7 & - & - & 1.9 & 0.8 & - & 7.8 & 5.7 \\
\hline $\begin{array}{l}\text { Neurodevelopmental } \\
\text { disorder }\end{array}$ & 6.1 & - & - & 1.4 & 1.6 & - & 3.4 & 7.8 \\
\hline Asthma & - & - & - & 0.9 & 0.7 & - & 1.4 & 2.8 \\
\hline Obesity & - & - & - & 0.1 & 0.5 & - & 0.4 & 1.6 \\
\hline Heart disease & - & - & - & 0.6 & 0.5 & - & 1.7 & 3.6 \\
\hline $\begin{array}{l}\text { Malignant neoplasm } \\
\text { excluding non- } \\
\text { melanoma skin cancer }\end{array}$ & - & - & - & 0.1 & 0.1 & - & 0.2 & 1.2 \\
\hline Hypertension & - & - & - & 0.1 & 0.1 & - & 0.5 & 0.9 \\
\hline Type 1 diabetes mellitus & 0.2 & - & - & 0.3 & 0.2 & - & 0.8 & 0.8 \\
\hline $\begin{array}{l}\text { Attention deficit } \\
\text { hyperactivity disorder }\end{array}$ & 1.8 & - & - & 0.6 & 1.0 & - & 1.0 & 3.7 \\
\hline Chromosomal disorder & 0.3 & - & - & 0.7 & 0.3 & - & 2.9 & 2.1 \\
\hline $\begin{array}{l}\text { Congenital } \\
\text { malformation }\end{array}$ & 9.2 & - & - & 2.6 & 1.7 & - & 10.4 & 8.7 \\
\hline
\end{tabular}


medRxiv preprint doi: https://doi.org/10.1101/2020.10.29.20222083; this version posted October 30, 2020. The copyright holder for this preprint (which was not certified by peer review) is the author/funder, who has granted medRxiv a license to display the preprint in perpetuity.

It is made available under a CC-BY 4.0 International license.

\begin{tabular}{|c|c|c|c|c|c|c|c|c|}
\hline $\begin{array}{l}\text { Congenital heart } \\
\text { disease }\end{array}$ & 0.2 & - & - & 0.6 & 0.3 & - & 2.8 & 1.9 \\
\hline Prematurity of infant & 0.8 & - & - & 0.5 & 0.5 & - & 2.6 & 2.9 \\
\hline \multicolumn{9}{|l|}{ Symptoms at index date } \\
\hline Fever & 5.2 & 9.6 & 8.7 & 14.7 & 9.9 & 10 & 12.2 & 23.7 \\
\hline Cough & 4.5 & 7.5 & 9.1 & 11.5 & 6.6 & 5.6 & 6.2 & 8.0 \\
\hline Dyspnea & 0.3 & - & 4.5 & 4.6 & 1.7 & 9.6 & 11.2 & 7.0 \\
\hline Malaise or fatigue & - & 1.6 & - & 1.1 & 1.0 & - & 1.0 & 1.3 \\
\hline Myalgia & - & - & - & 0.3 & 0.6 & - & 0.2 & 1.2 \\
\hline $\begin{array}{l}\text { Anosmia OR Hyposmia } \\
\text { OR Dysgeusia }\end{array}$ & - & - & - & 0.4 & 0.7 & - & - & $<0.7$ \\
\hline $\begin{array}{l}\text { Gastrointestinal tract } \\
\text { symptoms }\end{array}$ & 11.8 & 3.7 & - & 5.4 & 3.9 & 8.0 & 10.9 & 14.0 \\
\hline Diarrhea & 3.7 & - & - & 1.6 & 1.7 & - & 2.4 & 5.1 \\
\hline Vomiting & 1.7 & 1.6 & - & 3.2 & 1.9 & 2.4 & 7.5 & 7.8 \\
\hline Nausea & 1.4 & 1.6 & - & 1.2 & 1.1 & 2.0 & 2.6 & 3.5 \\
\hline Bronchiolitis & 1.3 & - & - & 6.6 & 1.1 & - & 21.9 & 8.0 \\
\hline
\end{tabular}

30-day outcomes

\begin{tabular}{|l|l|l|l|l|l|l|l|l|}
\hline Death & - & - & - & - & - & - & - & - \\
\hline Hospitalization episodes & 0.5 & - & 3.8 & 12.6 & 6.4 & 100 & 97.7 & 100 \\
\hline $\begin{array}{l}\text { Pneumonia } \\
\text { Multi-system }\end{array}$ & 0.1 & - & - & 4.0 & 1.0 & 6.4 & 19.5 & 10.2 \\
\hline $\begin{array}{l}\text { inflammatory syndrome } \\
\text { in children (MIS-C) }\end{array}$ & - & - & - & 0.2 & 0.5 & - & & \\
\hline
\end{tabular}

30-day outcomes during hospitalization

\begin{tabular}{|l|l|l|l|l|l|l|l|l|}
\hline Sepsis & - & - & - & 1.2 & 0.7 & - & 6.0 & 7.9 \\
\hline $\begin{array}{l}\text { Acute respiratory } \\
\text { distress syndrome } \\
\text { (ARDS) }\end{array}$ & - & - & - & 3.1 & 1.0 & - & 16.1 & 10.7 \\
\hline $\begin{array}{l}\text { Cardiac arrhythmia } \\
\text { (ARD) }\end{array}$ & - & - & - & 0.9 & 0.3 & - & 5.0 & 2.9 \\
\hline
\end{tabular}


medRxiv preprint doi: https://doi.org/10.1101/2020.10.29.20222083; this version posted October 30, 2020. The copyright holder for this preprint (which was not certified by peer review) is the author/funder, who has granted medRxiv a license to display the preprint in perpetuity.

It is made available under a CC-BY 4.0 International license.

\begin{tabular}{|l|l|l|l|l|l|l|l|l|}
\hline Bleeding & - & - & - & 0.3 & 0.3 & - & 1.9 & 3.3 \\
\hline
\end{tabular}

*Proportions presented among diagnosed or hospitalized patients by database (column percentage); - data not available or below the minimum cell count required ( 5 individuals).

**Comorbidities are reported only in those databases with at least 1 year of prior observation time.

Abbreviations: Colorado University Anschuz Medical Campus Health Data Compass (CU-AMC HDC), Columbia University Irving Medical Center (CUIMC), Data Analyzer (DA), Health Insurance Review \& Assessment Service (HIRA), Information System for Research in Primary Care (SIDIAP), STAnford medicine Research data Repository (STARR-OMOP), Longitudinal Patient Data (LPD). 